Prepared in cooperation with the South Dakota Department of Transportation

\title{
Estimation of Potential Scour at Bridges on Local Government Roads in South Dakota, 2009-12
}

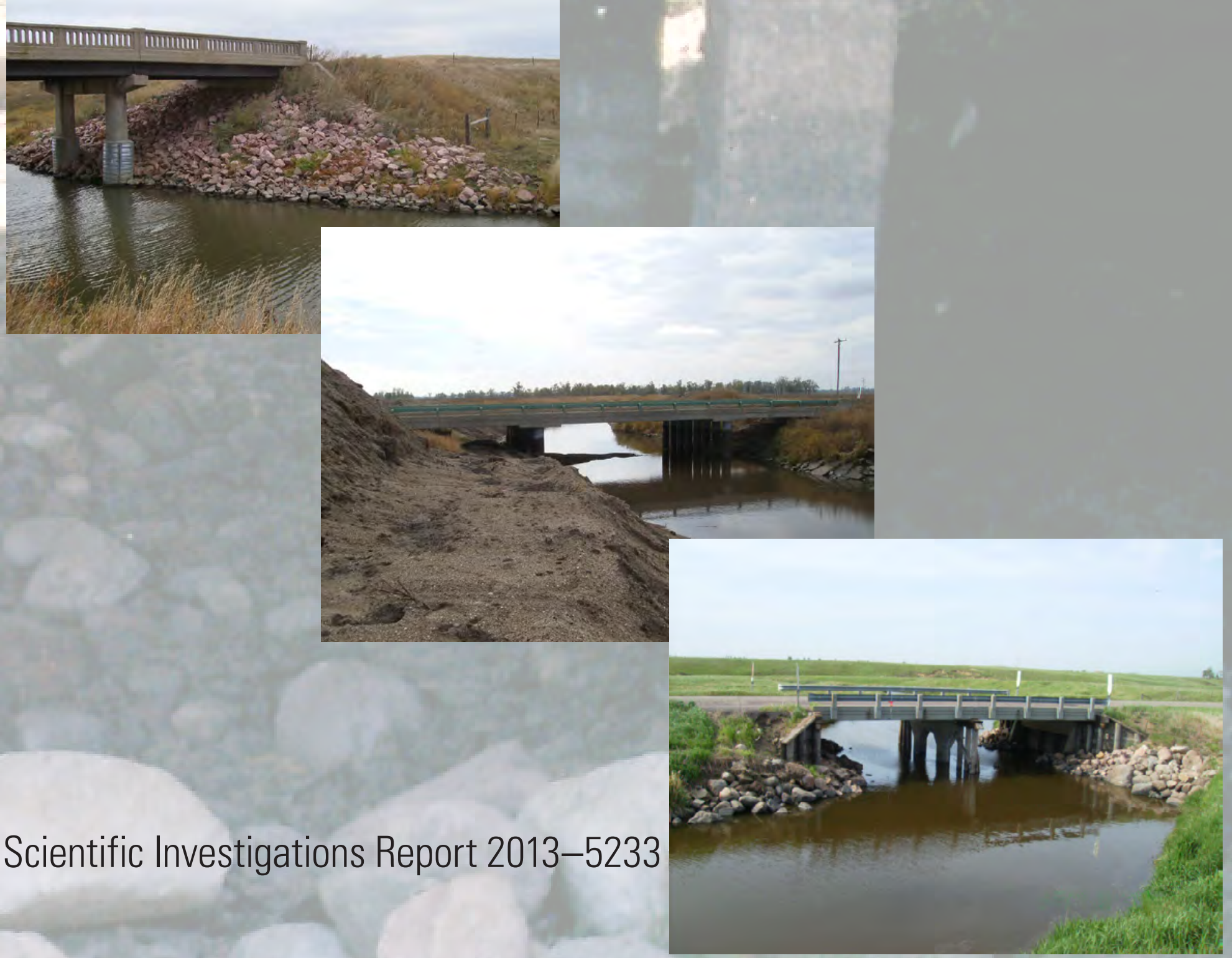

U.S. Department of the Interior U.S. Geological Survey 
Cover. Top to bottom: Riprap at right abutment and reinforced piers at bridge 03350048 over Shue Creek in Beadle County, South Dakota, October 7, 2011. Photograph by Ryan Thompson, U.S. Geological Survey. Evidence of recent channel cleanout upstream from bridge 06131130 over North Deer Creek in Brookings County, South Dakota, October 12, 2011. Photograph by Ryan Thompson, U.S. Geological Survey. Fieldstone riprap at upstream entrance to bridge 03334240 over Middle Pearl Creek in Beadle County, South Dakota, May 15, 2012. Photograph by Chelsea Wattier, U.S. Geological Survey. 


\section{Estimation of Potential Scour at Bridges on Local Government Roads in South Dakota, 2009-12}

By Ryan F. Thompson, Chelsea M. Wattier, Richard R. Liggett, and Ryan A. Truax

Prepared in cooperation with the South Dakota Department of Transportation

Scientific Investigations Report 2013-5233 


\title{
U.S. Department of the Interior SALLY JEWELL, Secretary
}

\section{U.S. Geological Survey Suzette M. Kimball, Acting Director}

\author{
U.S. Geological Survey, Reston, Virginia: 2014
}

For more information on the USGS - the Federal source for science about the Earth, its natural and living resources, natural hazards, and the environment, visit http://www.usgs.gov or call 1-888-ASK-USGS.

For an overview of USGS information products, including maps, imagery, and publications, visit http://www.usgs.gov/pubprod

To order this and other USGS information products, visit http://store.usgs.gov

Any use of trade, firm, or product names is for descriptive purposes only and does not imply endorsement by the U.S. Government.

Although this information product, for the most part, is in the public domain, it also may contain copyrighted materials as noted in the text. Permission to reproduce copyrighted items must be secured from the copyright owner.

Suggested citation:

Thompson, R.F., Wattier, C.M., Liggett, R.R., and Truax, R.A., 2014, Estimation of potential scour at bridges on local government roads in South Dakota, 2009-12: U.S. Geological Survey Scientific Investigations Report 2013-5233, 22 p., http://dx.doi.org/10.3133/sir20135233.

ISSN 2328-0328 (online) 


\section{Contents}

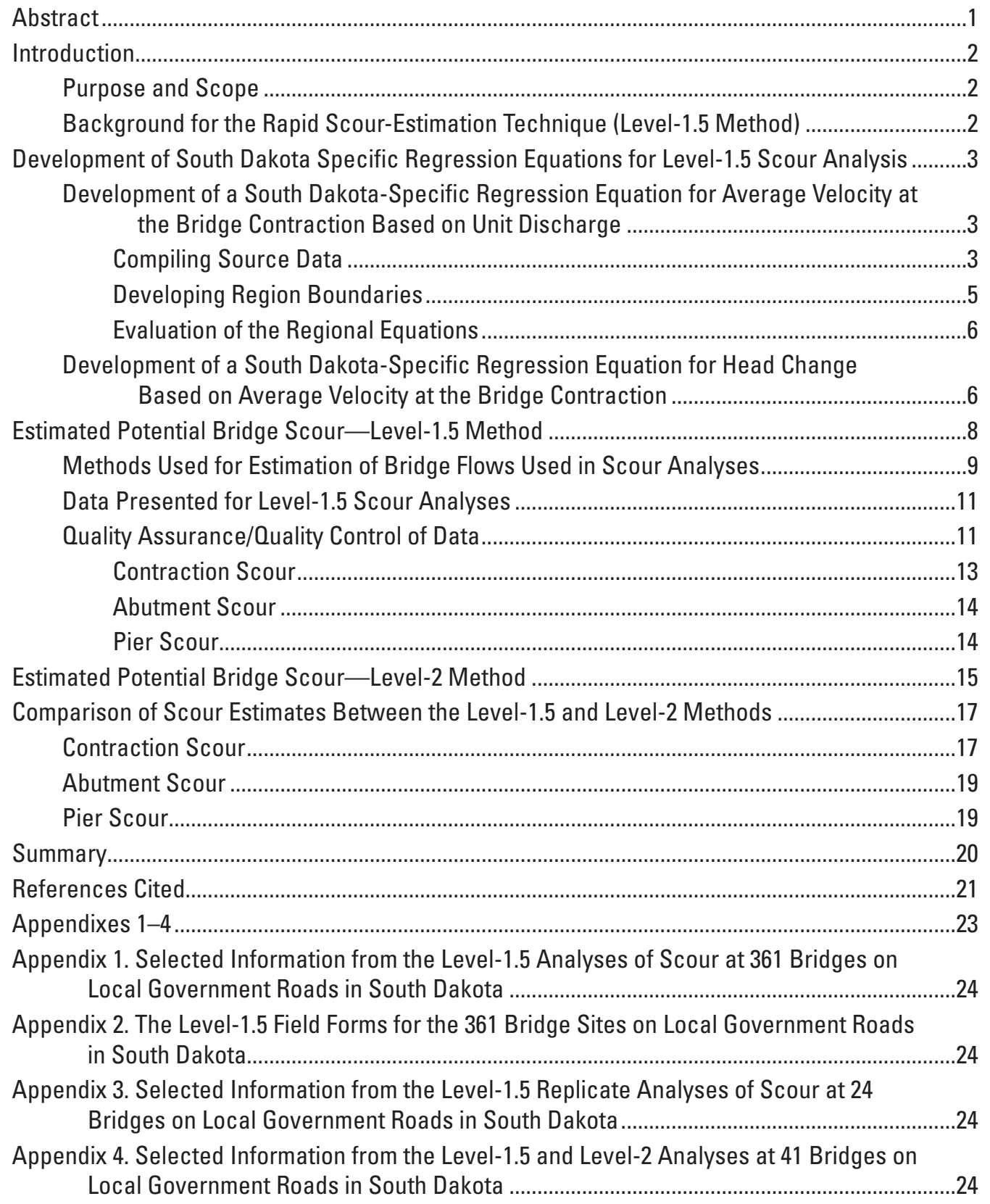




\section{Figures}

1. Map showing level-2 sites and streamgages contributing data to the velocity regression equation

2. Graph showing data from level-2 hydraulic models and streamflow measurements used in the velocity regression.

3. Map showing regions for South Dakota regressions between average velocity at the bridge contraction and unit discharge

4. Graph showing velocity regression data and regression equations color-coded by region.

5. Graph showing head change regression data color-coded by region and regression equation developed using data for all regions combined in South Dakota.

6. Map showing locations of South Dakota bridges where level-1.5 analyses were completed

7. Map showing locations of South Dakota bridges with replicate level-1.5 bridge scour analyses.

8. Graph showing replicate level-1.5 contraction scour estimates at 24 bridge sites in South Dakota

9. Graph showing replicate level-1.5 abutment scour estimates at 24 bridge sites in South Dakota

10. Graph showing replicate level-1.5 pier scour estimates at 24 bridge sites in South Dakota

11. Map showing locations of South Dakota bridges receiving a level-1.5 and level-2 bridge scour analysis, 2009-12.

12. Graph showing relation of estimated contraction scour between level-1.5 and level-2 analyses .....

13. Graph showing relation of estimated abutment scour between level-1.5 and level-2 analyses ......

14. Graph showing relation of estimated pier scour between level-1.5 and level-2 analyses

\section{Tables}

1. Summary of velocity regression data and regression equations by region .......................6

2. Summary of statewide head change regression data and regression equation ..............8 


\section{Conversion Factors}

Inch/Pound to SI

\begin{tabular}{lcc}
\hline \multicolumn{1}{c}{ Multiply } & By & To obtain \\
\hline foot $(\mathrm{ft})$ & Length & meter $(\mathrm{m})$ \\
\hline & 0.3048 & \\
\hline square mile $\left(\mathrm{mi}^{2}\right)$ & Area & square kilometer $\left(\mathrm{km}^{2}\right)$ \\
\hline & 2.590 & \\
\hline cubic foot per second $\left(\mathrm{ft}^{3} / \mathrm{s}\right)$ & Flow rate & cubic meter per second $\left(\mathrm{m}^{3} / \mathrm{s}\right)$ \\
\hline
\end{tabular}

Vertical coordinate information is referenced to the North American Vertical Datum of 1988 (NAVD 88).

Horizontal coordinate information is referenced to the North American Datum of 1983 (NAD 83). 


\section{Abbreviations}

$\Delta h$

$K_{1}$

$\mathrm{K}_{2}$

$\mathrm{O}_{2}$

$O_{5}$

$Q_{10}$

$Q_{25}$

$0_{50}$

$Q_{100}$

$Q_{500}$

$Q_{\text {max scour }}$

$Q_{\text {low steel }}$

$q_{2}$

$R^{2}$

$V_{2}$

$W_{1}$

$y_{\mathrm{cs}}$

$Y_{\text {lob }}$

$Y_{\text {rob }}$

AEP

GPS

HEC-RAS

HIRE

RTK-GNSS

SDDOT

USGS change in head from the approach section to the bridge exit

abutment shape coefficient

correction factor for flow angle of attack

annual exceedance probability of 50 percent (2-year flood)

annual exceedance probability of 20 percent (5-year flood)

annual exceedance probability of 10 percent (10-year flood)

annual exceedance probability of 4 percent (25-year flood)

annual exceedance probability of 2 percent (50-year flood)

annual exceedance probability of 1 percent (100-year flood)

annual exceedance probability of 0.2 percent (500-year flood)

flow estimated to cause the maximum amount of scour

flow estimated to fill the bridge opening

unit discharge in cubic feet per second per foot-width of main channel at the contracted section

coefficient of determination

average main-channel velocity at the bridge contraction

width of main channel at approach section

estimated contraction scour depth

depth of flow, in feet, in left overbank at approach section

depth of flow, in feet, in right overbank at approach section

annual exceedance probability

global positioning system

Hydraulics Engineering Center River Analysis System

Hydraulics in the River Environment

real-time kinematic global navigation satellite system

South Dakota Department of Transportation

U.S. Geological Survey 


\title{
Estimation of Potential Scour at Bridges on Local Government Roads in South Dakota, 2009-12
}

\author{
By Ryan F. Thompson, Chelsea M. Wattier, Richard R. Liggett, and Ryan A. Truax
}

\section{Abstract}

In 2009, the U.S. Geological Survey and South Dakota Department of Transportation (SDDOT) began a study to estimate potential scour at selected bridges on local government (county, township, and municipal) roads in South Dakota. A rapid scour-estimation method (level-1.5) and a more detailed method (level-2) were used to develop estimates of contraction, abutment, and pier scour.

Data from 41 level-2 analyses completed for this study were combined with data from level-2 analyses completed in previous studies to develop new South Dakota-specific regression equations: four regional equations for main-channel velocity at the bridge contraction to account for the widely varying stream conditions within South Dakota, and one equation for head change. Velocity data from streamgages also were used in the regression for average velocity through the bridge contraction.

Using these new regression equations, scour analyses were completed using the level-1.5 method on 361 bridges on local government roads. Typically, level-1.5 analyses are completed at flows estimated to have annual exceedance probabilities of 1 percent (100-year flood) and 0.2 percent (500-year flood); however, at some sites the bridge would not pass these flows. A level-1.5 analysis was then completed at the flow expected to produce the maximum scour. Data presented for level-1.5 scour analyses at the 361 bridges include contraction, abutment, and pier scour. Estimates of potential contraction scour ranged from 0 to 32.5 feet for the various flows evaluated. Estimated potential abutment scour ranged from 0 to 40.9 feet for left abutments, and from 0 to 37.7 feet for right abutments. Pier scour values ranged from 2.7 to 31.6 feet. The scour depth estimates provided in this report can be used by the SDDOT to compare with foundation depths at each bridge to determine if abutments or piers are at risk of being undermined by scour at the flows evaluated.

Replicate analyses were completed at 24 of the 361 bridges to provide quality-assurance/quality-control measures for the level-1.5 scour estimates. An attempt was made to use the same flows among replicate analyses. Scour estimates do not necessarily have to be in numerical agreement to give the same results. For example, if contraction scour replicate analyses are 18.8 and 30.8 feet, both scour depths can indicate susceptibility to scour for which countermeasures may be needed, even though one number is much greater than the other number. Contraction scour has perhaps the greatest potential for being estimated differently in replicate visits. For contraction scour estimates at the various flows analyzed, differences between results ranged from -7.8 to 5.5 feet, with a median difference of 0.4 foot and an average difference of 0.2 foot. Abutment scour appeared to be nearly as reproducible as contraction scour. For abutment scour estimates at the varying flows analyzed, differences between results ranged from -17.4 to 11 feet, with a median difference of 1.4 feet and an average difference of 1.7 feet. Estimates of pier scour tended to be the most consistently reproduced in replicate visits, with differences between results ranging from -0.3 to 0.5 foot, with a median difference of 0.0 foot and an average difference of 0.0 foot.

The U.S. Army Corps of Engineers Hydraulics Engineering Center River Analysis Systems (HEC-RAS) software package was used to model stream hydraulics at the 41 sites with level-2 analyses. Level-1.5 analyses also were completed at these sites, and the performance of the level-1.5 method was assessed by comparing results to those from the more rigorous level-2 method. The envelope curve approach used in the level-1.5 method is designed to overestimate scour relative to the estimate from the level-2 scour analysis. In cases where the level-1.5 method estimated less scour than the level-2 method, the amount of underestimation generally was less than 3 feet. The level-1.5 method generally overestimated contraction, abutment, and pier scour relative to the level-2 method, as intended. Although the level-1.5 method is designed to overestimate scour relative to more involved analysis methods, many assumptions, uncertainties, and estimations are involved. If the envelope curves are adjusted such that the level-1.5 method never underestimates scour relative to the level-2 method, an accompanying result may be excessive overestimation. 


\section{Introduction}

Flowing water can erode (scour) soils and cause structural failure of a bridge by exposing or undermining bridge foundations (abutments and piers). Scour at bridge abutments and piers has historically been the most common cause of bridge failure within the United States (Butch, 1991). In 1988, the Federal Highway Administration recommended that every bridge over a scourable stream be evaluated as to its vulnerability to scour caused by floods (U.S. Department of Transportation, 1988).

In response to this recommendation, the U.S. Geological Survey (USGS) in cooperation with the South Dakota Department of Transportation (SDDOT) began a series of studies investigating bridge scour in South Dakota. During 1992-95, Niehus (1996) completed an assessment of scour susceptibility at 32 bridges and measured scour at 13 of these bridges. The same 13 bridges also were analyzed using the more detailed level-2 method. The level-2 method uses channel and bridge geometry information and hydraulics modeling software to estimate flow parameters required to solve scour depth equations. The Hydraulics Engineering Center's River Analysis System (HEC-RAS; Brunner, 2002a, b) was the hydraulics modeling software used for this study. During evaluation of additional bridges on State Routes (State and Federal highways) in South Dakota, Thompson and Fosness (2008) investigated 734 bridges and applied a rapid scour-estimation technique (level-1.5 method) developed in Montana (Holnbeck and Parrett, 1997). Scour at 19 of these bridges also was analyzed using the level-2 method, so that results of the two methods (level-1.5 and level-2) could be compared, and the suitability of the level-1.5 method could be tested for conditions in South Dakota. The level-1.5 method was determined to adequately estimate scour depths similar to those produced by level-2 analyses for bridges in South Dakota. However, Thompson and Fosness (2008) recognized the potential for developing a State-specific set of velocity and head change equations using data from bridges in South Dakota.

Beginning in 2009, the USGS and SDDOT began another study to estimate potential scour at selected bridges on local government (county, township, and municipal) roads in South Dakota. This study used the 19 previous level-2 analyses and pooled their output with data from level-2 analyses at an additional 41 sites distributed across South Dakota. These data, along with existing streamflow measurement data, were used to develop regions, within which regression equations for approach velocity (required for the level-1.5 method) were developed. Data from the pooled group of level-2 analyses also were used to develop a South Dakota-specific regression equation for head change between the approach section and the bridge exit (also required for the level-1.5 method).

The level-1.5 analyses include estimates for contraction, abutment, and pier scour. Contraction scour is the general lowering of the channel because of flow acceleration through the channel constriction caused by the bridge (Niehus, 1996). Contraction scour can result when the bridge abutments are constructed in the main channel or when the bridge is constructed in the flood plain of the river or stream. The river or stream flow tends to scour the channel bottom, increasing the flow area and consequently decreasing the flow velocity (Niehus, 1996). Abutment scour is caused by vortices formed where the flow accelerates around the structure. Pier scour is caused by the pileup of water on the upstream face of the pier and the resultant vortices that remove materials from the base area of the pier structure (Niehus, 1996). The scour depths estimated with the level-1.5 method can be used by the SDDOT and others to identify bridges that may be susceptible to scour and in need of preventative scour countermeasures.

\section{Purpose and Scope}

The purpose of this report is to present and summarize (1) the development of South Dakota-specific regression equations for average velocity at the bridge contraction on unit discharge, and head change on average velocity squared, using data from existing and newly acquired level-2 analyses of bridges and data from streamgages, (2) the potential bridge scour estimates from level-1.5 analyses at 361 bridges on local government roads in South Dakota, and (3) a comparison of scour estimates between level-1.5 and level-2 analyses at 41 bridges. Average velocity and head change from the South Dakota-specific regression equations were used in separate regression equations described in Holnbeck and Parrett (1997) to estimate contraction scour, abutment scour, and pier scour for the level-1.5 analyses.

The 41 level-2 bridge scour analyses for this study were completed during 2009, and the 361 level-1.5 bridge scour analyses for this study were completed during 2010-12. All bridges analyzed for this study were on scourable streams within or on boundary waters of the State of South Dakota.

\section{Background for the Rapid Scour-Estimation Technique (Level-1.5 Method)}

Bridge scour analyses typically are classified as level 1 , 2 , or 3 with the increase in level generally indicating a more complex analysis (Lagasse and others, 1991). Level-1 scour analyses are qualitative, general, and based on a visual inspection of the bridge and stream channel including evidence of past scour. Bridge size and geometry data may either be measured onsite or compiled from construction plans. Level-1 scour analyses take several minutes to an hour for one person to complete. Level-2 scour analyses are considerably more complex, and data collected at the site include channel profile and cross sections, bridge geometry, and properties of the streambed and overbank material. These data are then used in a hydraulics model to calculate flow parameters, such as velocity and depth, which are in turn used in any of several 
published scour equations (Richardson and others, 1991) to solve for scour depth. Level-2 scour analyses require a considerable amount of data collection effort and may take 1 or more weeks to complete. Level-3 scour analyses generally are reserved for complex situations or forensic purposes and involve extensive mathematical and physical modeling of the selected bridge.

A rapid scour-estimation technique, known as the level1.5 method, was developed by the USGS for evaluating scour at bridges in Montana (Holnbeck and Parrett, 1997). This method uses limited site data to quantitatively estimate contraction, abutment, and pier scour. One person can complete a level-1.5 analysis in 1 to 3 hours. Although the level-1.5 method is not intended to replace the more detailed level-2 method, it is useful for completing limited-effort analyses that yield a quantitative result.

The level-1.5 method uses one or more estimates of flow and bridge dimensions to iteratively estimate a width of flow and resultant depth of flow through the bridge opening. From this estimated flow depth, equations developed from data regression are used to estimate velocity and head change between the approach section and the bridge exit. The depth of flow is extended upstream (taking into account head change through the bridge opening) with the use of a hand level to an approach section where flow width and depth are estimated for the left and right overbank areas. Separate equations are then used to estimate contraction scour, abutment scour, and pier scour if applicable. The level-1.5 method includes a test for clear-water or live-bed contraction scour conditions and has separate equations for each condition. Clear-water contraction scour conditions result when the channel velocity is not sufficient to transport bed material, whereas live-bed contraction scour conditions result when the channel velocity is sufficient to transport bed material. An envelope curve approach is used so that scour depths tend to be overestimated rather than underestimated. Moderate overestimation allows for a margin of error while still identifying sites that are potentially at risk for excessive scour. More detailed descriptions of the level-1.5 method and the derivation of the scour equations used are provided in Holnbeck and Parrett (1997).

Before this study, South Dakota did not have a sufficient number of bridge scour analyses completed with the level-2 method to develop a State-specific set of regression equations for main-channel velocity at the bridge contraction or for head change. Therefore, equations 52 (average velocity at the bridge contraction based on unit discharge at the bridge contration) and 53 (water surface elevation difference based on average velocity at the bridge contraction, squared), respectively, of Holnbeck and Parrett (1997) were used to compute these parameters for the earlier level-1.5 study completed for 734 bridges on State routes in South Dakota (Thompson and Fosness, 2008). The following section describes how the South Dakota-specific set of equations were developed for this level-1.5 study of bridges on local government roads.

\section{Development of South Dakota Specific Regression Equations for Level-1.5 Scour Analysis}

Thompson and Fosness (2008) determined that although equations 52 and 53 of Holnbeck and Parrett (1997) were applicable to most areas of South Dakota, velocities recorded during streamgaging activities on the James River in eastern South Dakota were known to be substantially lower than those produced by equation 52 . By combining data from level-2 analyses completed by Niehus (1996), and the 19 level-2 analyses completed during the study of bridges on State routes, Thompson and Fosness (2008) developed a set of alternate velocity and head change equations using data from South Dakota, but suggested that the effort be revisited when additional level-2 analyses became available. Therefore, 41 additional level-2 analyses were completed for this report to achieve a more even distribution of sites across the State. Analyses from these 41 sites, along with the previously completed analyses for level-2 sites, were used to generate data to develop new regression equations for average velocity at the bridge contraction based on unit discharge, and head change based on average velocity at the bridge contraction. Velocity data from streamgages also were used in the regression equations for average velocity through the bridge opening. Development of the regression equations for average velocity at the bridge contraction based on unit discharge, and head change based on average velocity at the bridge contraction are summarized in the following sections.

\section{Development of a South Dakota-Specific Regression Equation for Average Velocity at the Bridge Contraction Based on Unit Discharge}

Development of velocity regression equations for level1.5 bridge scour analyses in South Dakota involved compiling an appropriate pool of source data, developing region boundaries within the State, and evaluating the resulting regional equations. The methodology for these processes is described in the following sections.

\section{Compiling Source Data}

Data from two sources were used to develop a regression equation for average velocity through the bridge contraction based on unit discharge at the bridge contraction. Data from the 41 hydraulic models constructed for level-2 analyses in this study and data from the 19 hydraulic models constructed for level-2 analyses by Thompson and Fosness (2008) in combination with data from streamflow measurements at streamgages in figure 1 (U.S. Geological Survey, 2013a) were used to develop regression equations. Data from the 13 level-2 bridge sites analyzed by Niehus (1996) could not be included 


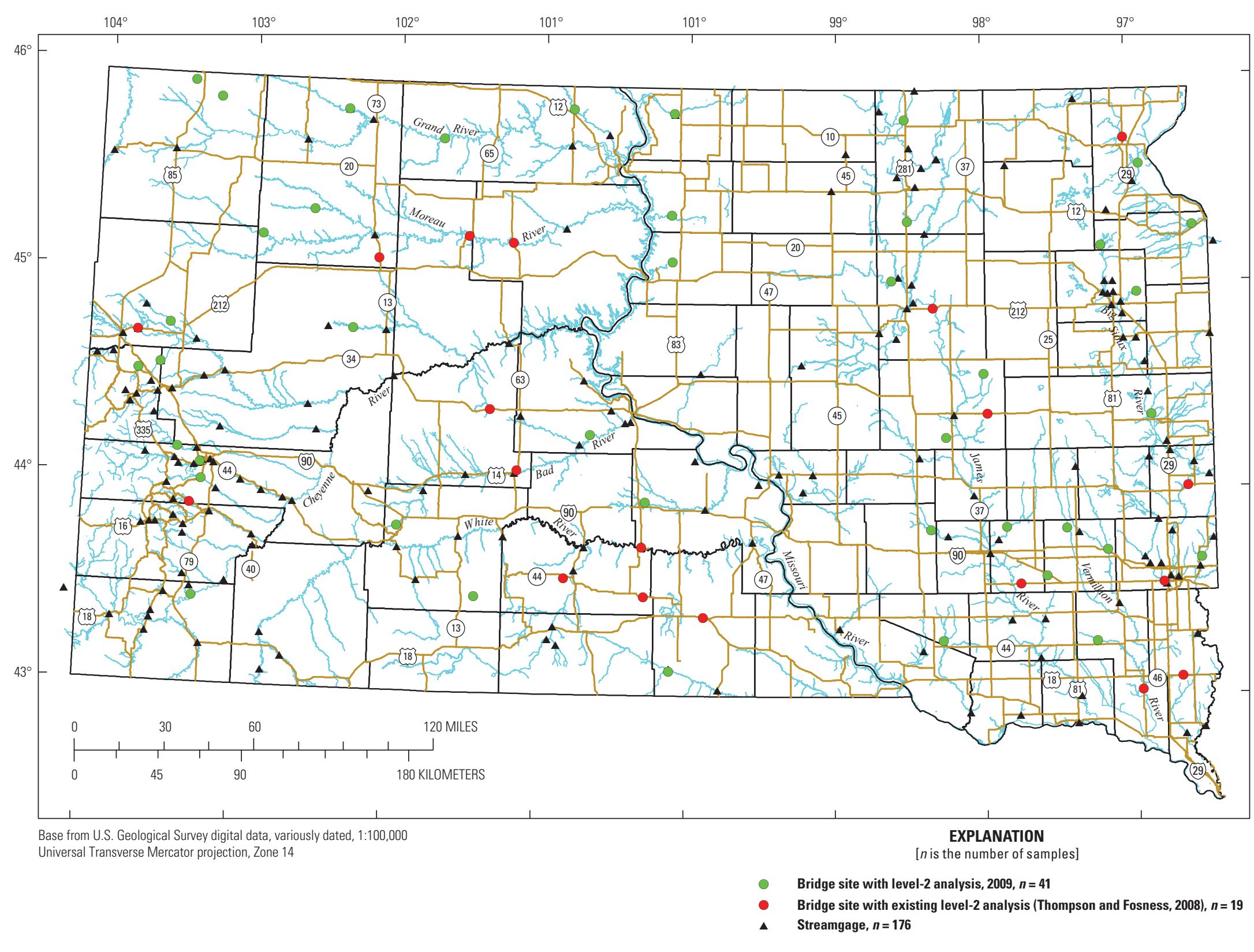

Figure 1. Level-2 sites and streamgages contributing data to the velocity regression equation. 
because the models used in that study did not contain all of the field data required to construct HEC-RAS models. Because the scour events targeted by this study happen in conjunction with high-flow events, the data output from the hydraulic models needed to be limited to flow scenarios where the bridge opening was acting as a flow constriction. Likewise, the data from streamgages needed to be limited to measurements made at bridges during high-flow events, and unaffected by ice jams or other factors causing backwater. Additional data screening from the hydraulic models was used to eliminate data that were affected by a change in flow regime, such as a change to supercritical flow or a hydraulic jump (an abrupt rise in the water surface) through the bridge. Following screening, the velocity regression was completed using 605 data points from hydraulic models at 60 level-2 bridge analysis sites, and 1,323 data points from streamflow measurements made at 176 streamgages (fig. 2). Field data from the streamflow measurements generally match the hydraulic model output data. However, these South Dakota-specific data indicate a different slope and y-intercept than equation 52 of Holnbeck and Parrett (1997).

\section{Developing Region Boundaries}

An effort was made to explore the possibility of regionalizing the velocity regression equations to better reflect the widely varying stream conditions within South Dakota. Initially, five regions were proposed, with boundaries being roughly based on the peakflow magnitude regions used by Sando (1998) and the ecoregions of Bryce and others (1998). Region 1 (not shown) corresponded approximately to the Black Hills Interior and Black Hills Exterior regions of Sando (1998) plus the Black Hills Plateau ecoregion of Bryce and others (1998). Region 2 (not shown) consisted of the remainder of the State west of the Missouri River. Region 3 (not shown) covered the part of the State east of the Missouri River, excluding part of the upper James Basin and an area roughly corresponding to region A of Sando (1998). Region 4 (not shown) was largely equivalent to Sando's (1998) region A, which approximated the Minnesota-Red River Lowlands, the Coteau des Prairies, and the eastern part of the Southern Plateaus ecoregions of Bryce and others (1998). Region 5 (not shown) was the area locally known

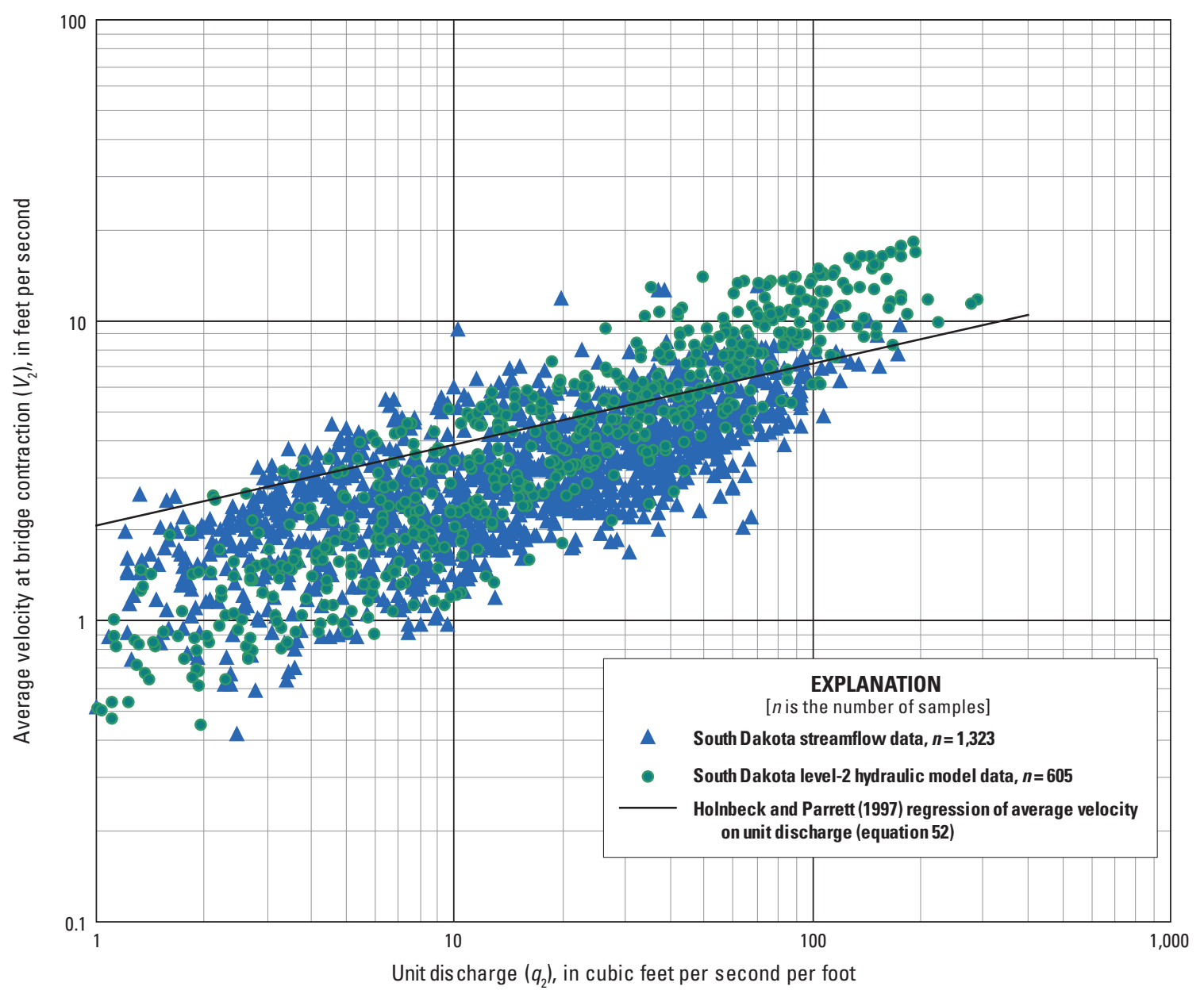

Figure 2. Data from level-2 hydraulic models and streamflow measurements used in the velocity regression. 
as the Aberdeen Plateau, and approximated the Drift Plains, Glacial Lakes Basins, and Glacial Lakes Deltas ecoregions of Bryce and others (1998). These five preliminary regions were realigned into four final regions. Preliminary region 1 became final region $\mathrm{A}$, and preliminary region 2 became final region $\mathrm{B}$ fig. 3). Preliminary regions 3 and 4 were combined into final region C (fig. 3) because their data largely overlapped and their equations were similar. Preliminary region 5 became final region D (fig. 3).

\section{Evaluation of the Regional Equations}

The regional equations can be evaluated visually. A plot of the data, color-coded by region, shows distinct banding (fig. 4). A summary of the data used and the final velocity regression equations for each region are shown in table 1. The coefficient of determination $\left(R^{2}\right)$ values (fraction of the total squared error that is explained by the equation) for these regionalized velocity regression equations are higher than those for Montana $\left(R^{2}=0.31\right.$, not shown, Holnbeck and Parrett, 1997), North Dakota $\left(R^{2}=0.38\right.$, not shown, WilliamsSether, 1999), Missouri ( $R^{2}=0.36$ for Central Lowlands and $R^{2}=0.49$ for Ozark Plateaus, not shown, Huizinga and Rydlund, 2004), and the previous South Dakota study $\left(R^{2}=\right.$ 0.43, Thompson and Fosness, 2008). Although part of this improvement may be an indication that more regions allow the data to fit their respective regional equations better, it is probably largely because multiple data points were used from most sites, and the data from each site covered a range of high flows instead of one specific flow, such as the flow estimated for an annual exceedance probability (AEP) of 1 percent or also known as the 100-year flood (Holmes and Dinicola, 2010). Using data representing a range of high flows was a strategy developed because it was anticipated that some of the local government bridges were designed for flows less than those estimated for the 1-percent AEP (100-year flood). Additional information on the selection of flows used for level-1.5 analysis is provided in the "Methods Used for Estimation of Bridge Flows Used in Scour Analyses" section of this report.

\section{Development of a South Dakota-Specific Regression Equation for Head Change Based on Average Velocity at the Bridge Contraction}

Hydraulic models for level-2 analyses sites provided the only data for the head change regression because streamflow measurements typically do not include enough information to determine the water surface at the approach section. As in the velocity regression, the data from the hydraulic models needed to be limited to flow scenarios where the bridge opening was acting as a flow constriction, and where the flow regime did not change in the bridge opening. Three of the level-2 sites did not meet these criteria. Therefore, 227 data points from hydraulic models at 57 level-2 bridge analysis sites were used to develop the regression equation for head change based on average velocity at the bridge contraction. The head change data are shown in figure 5 color coded by the regions shown in figure 3 . However, unlike the velocity data, no banding by region was evident. Instead the data were combined to form a single statewide equation, as summarized in table 2 . The line representing the head change regression for all regions combined in South Dakota has a lower slope than equation 53 of Holnbeck and Parrett (1997) (fig. 5). Although the head change regression for South Dakota has a higher coefficient of determination $\left(R^{2}=0.93\right)$ than equation 53 of Holnbeck and Parrett (1997; $\left.R^{2}=0.59\right)$, much of the increase could be due to a range of values being used for each site, rather than a single value.

Table 1. Summary of velocity regression data and regression equations by region.

$\left[R^{2}\right.$, coefficient of determination and is the fraction of the total squared error that is explained by the equation]

\begin{tabular}{ccccccc}
\hline $\begin{array}{c}\text { Region } \\
\text { (fig. 3) }\end{array}$ & $\begin{array}{c}\text { Number of } \\
\text { level-2 sites } \\
\text { used in region }\end{array}$ & $\begin{array}{c}\text { Number of } \\
\text { level-2 data } \\
\text { points in region }\end{array}$ & $\begin{array}{c}\text { Number of } \\
\text { streamgages } \\
\text { contributing data } \\
\text { in region }\end{array}$ & $\begin{array}{c}\text { Number of } \\
\text { streamgage data } \\
\text { points in region }\end{array}$ & Equation ${ }^{1}$ & $\boldsymbol{R}^{\mathbf{2}}$ \\
\hline $\mathrm{A}$ & 7 & 70 & 43 & 269 & $V_{2}=1.3921 q_{2}^{0.4518}$ & 0.7416 \\
$\mathrm{~B}$ & 24 & 240 & 56 & 415 & $V_{2}=0.9344 q_{2}^{0.4736}$ & 0.7694 \\
$\mathrm{C}$ & 26 & 255 & 61 & 515 & $V_{2}=0.7068 q_{2}^{0.5007}$ & 0.7628 \\
$\mathrm{D}$ & 4 & 40 & 16 & 121 & $V_{2}=0.5544 q_{2}^{0.4697}$ & 0.8339 \\
\hline
\end{tabular}

${ }^{1} V_{2}$ is mean velocity, in feet per second, at the bridge contraction; $q_{2}$ is unit discharge, in cubic feet per second per foot of width, at the contracted section. 


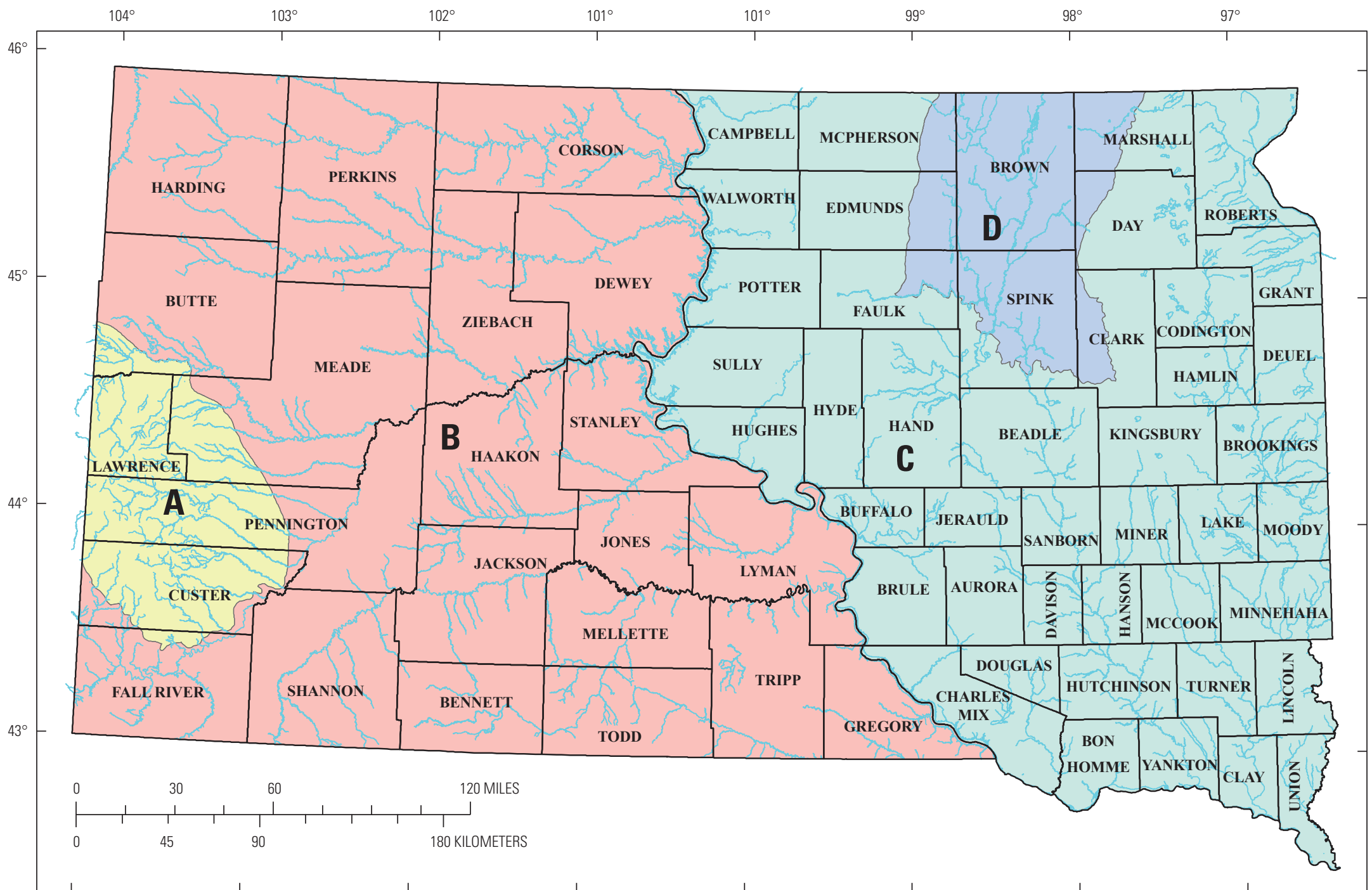

Base from U.S. Geological Survey digital data, variously dated, 1:100,000

EXPLANATION

Universal Transverse Mercator projection, Zone 14

Velocity regression region

A

Figure 3. Regions for South Dakota regressions between average velocity at the bridge contraction and unit discharge. 


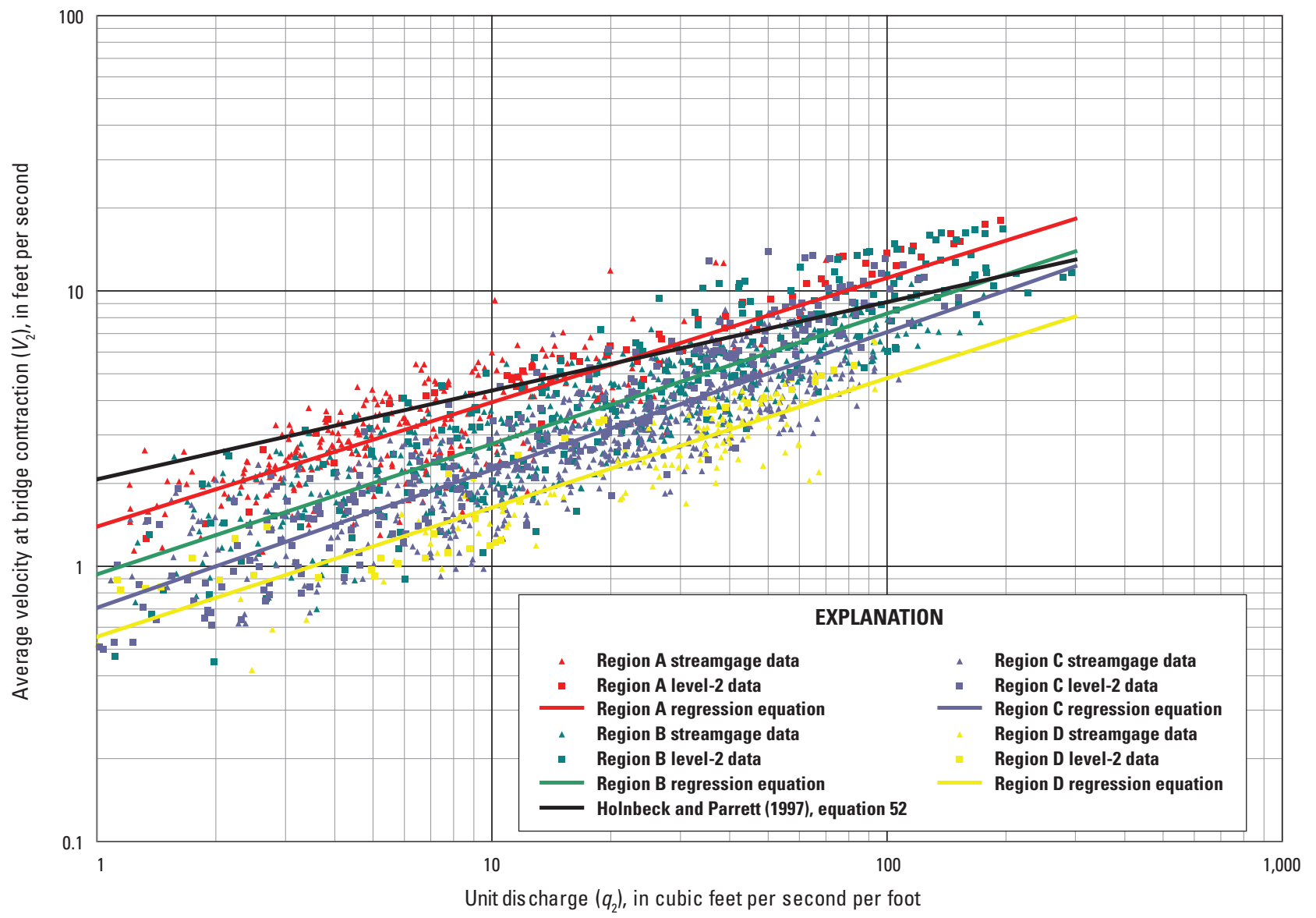

Figure 4. Velocity regression data and regression equations color-coded by region.

Table 2. Summary of statewide head change regression data and regression equation.

$\left[R^{2}\right.$, coefficient of determination $]$

\begin{tabular}{cccc}
\hline $\begin{array}{c}\text { Number } \\
\text { of level-2 } \\
\text { sites used }\end{array}$ & $\begin{array}{c}\text { Number of } \\
\text { level-2 data } \\
\text { points }\end{array}$ & Equation ${ }^{1}$ & $\boldsymbol{R}^{2}$ \\
\hline 57 & 227 & $\Delta h=0.02067 V_{2}^{2}-0.00952$ & 0.92861 \\
\hline
\end{tabular}

${ }^{1} \Delta h$ is the change in head, in feet, from the approach section to the bridge exit; $V_{2}$ is the mean velocity, in feet per second at the bridge contraction.

\section{Estimated Potential Bridge Scour- Level-1.5 Method}

When Thompson and Fosness (2008) completed the level-1.5 bridge scour study of 734 bridges on State Routes, there also were more than 3,300 bridges on local government roads in South Dakota according to the National Bridge Inventory database (U.S. Department of Transportation, 2013). Many of these bridges are more than 50 years old, and some date back to the Work Projects Administration of the 1930s (South Dakota State Historical Society, 2013). For many of the older bridges, construction drawings or as-built drawings are not available, and foundation depths of piers and abutments are unknown. If foundation depths are not known, it is not possible to determine if estimated scour depths will cause a given bridge to be vulnerable or potentially critically scour. For this reason, bridges with unknown foundation depths were not investigated in this study. Additional bridges were scheduled for replacement in the near future and also were excluded. This resulted in approximately 730 bridges remaining. In 2010, after initial phases of the study were underway, the Federal Highway Administration agreed to exempt scour analysis requirements on bridges with an average daily traffic count of less than 100 . This further reduced the number of bridges requiring level-1.5 analysis to approximately 336 . However, some of the bridges analyzed in 2009 had average daily traffic counts less than 100, but were still included in the study. A few bridges spanned impounded water bodies, such as lakes or reservoirs. Because a few of the basic assumptions of the level-1.5 method are not well suited to this situation, impounded sites could not receive a complete level-1.5 evaluation. Estimating or measuring the necessary variables also becomes difficult if water is too deep to wade or the bridge opening is so wide that use of a hand 


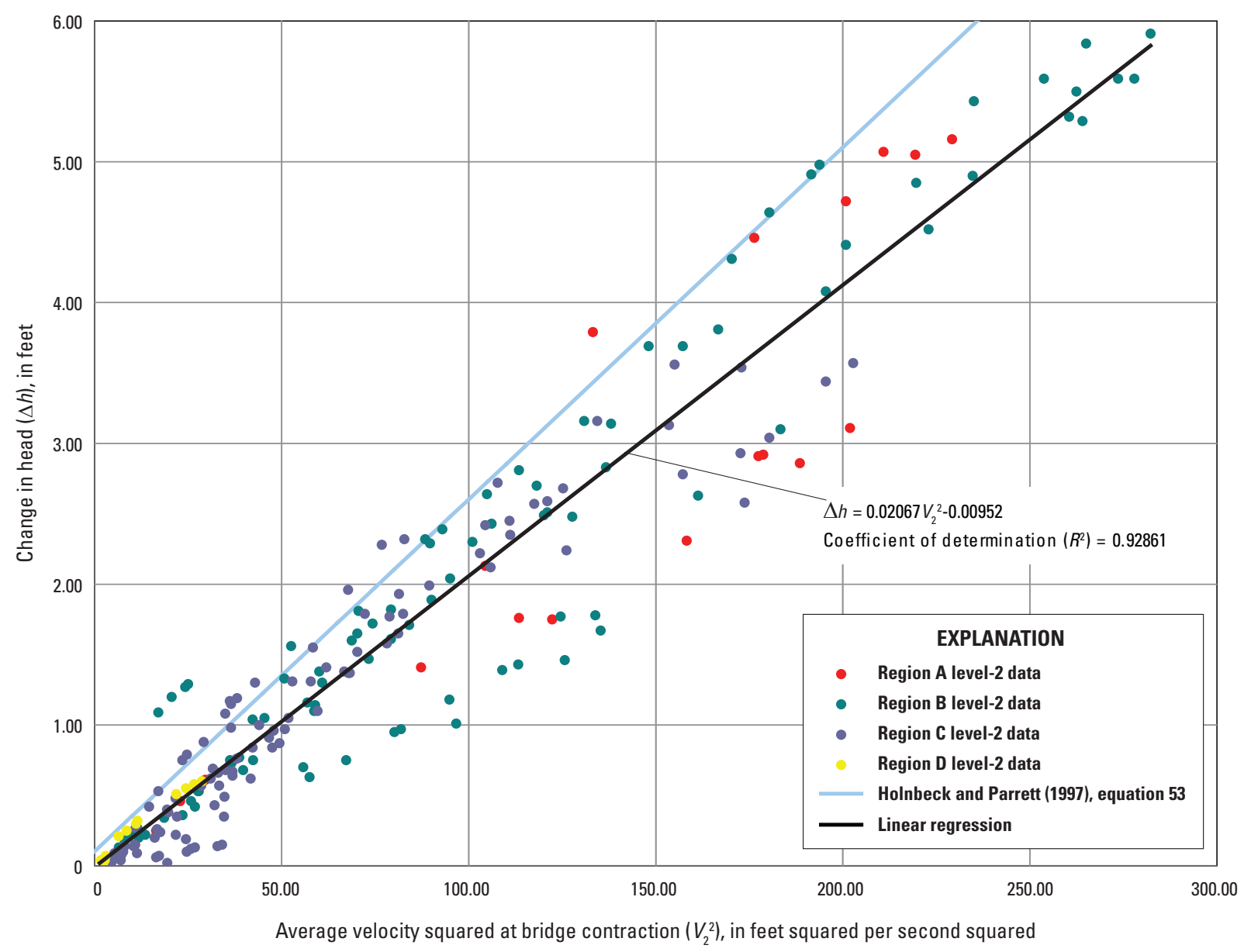

Figure 5. Head change regression data color-coded by region and regression equation developed using data for all regions combined in South Dakota.

level introduces unacceptable errors. A few additional bridges could not receive a complete analysis because they were too long for application of the level-1.5 method. Figure 6 shows the locations of 361 bridges for which scour analyses were completed by using the level-1.5 method. Location and other information for the 361 bridges are presented in appendix 1 as a Microsoft ${ }^{\circledR}$ Excel spreadsheet.

\section{Methods Used for Estimation of Bridge Flows Used in Scour Analyses}

Thompson and Fosness (2008) typically conducted level-1.5 analyses at flows estimated to be the 1-percent and 0.2-percent AEPs (100- and 500-year floods, respectively) for each bridge. At some sites, the bridge would pass the 1-percent AEP flow (100-year flood; $Q_{100}$ ) but not the 0.2-percent AEP flow (500-year flood; $Q_{500}$ ), whereas at other sites, the bridge would not pass the $Q_{100}$ or $Q_{500}$ flow. For these sites, some portion of the $Q_{500}$ flow, or some portion of the $Q_{100}$ and $Q_{500}$ flow, passes through the bridge, whereas the remainder of the flow moves downstream by way of road overflow, bridge overtopping, or both. To complete level-1.5 analyses at such sites, the amount of flow passing through the bridge was estimated and recorded on the field form, and an analysis was completed at that flow. For this study, a similar strategy was used. If a bridge could not pass the $Q_{100}$ flow, a level1.5 analysis was completed at the flow expected to produce the maximum scour $\left(Q_{\max \text { scour }}\right)$. This was typically the lower of either bridge-full conditions (flow estimated to fill the bridge opening; $Q_{\text {low steel }}$, or the point at which road overflow begins. If a bridge could pass the $Q_{100}$ flow but not the $Q_{500}$ flow, the level-1.5 analyses were completed at the $Q_{100}$ flow and the estimated $Q_{\max \text { scour }}$. If a bridge could pass the $Q_{100}$ and $Q_{500}$ flows, both these flows were given a level-1.5 analysis. If the bridge was capable of passing a flow greater than the $Q_{500}$ flow, no additional evaluation was completed. In cases where the $Q_{\max \text { scour }}$ was less than the $Q_{100}$ flow, sometimes an additional evaluation was completed at the 50-, 20-, 10-, 4-, or 2-percent AEP flows (2-, 5-, 10-, 25-, or 50-year floods, respectively; $Q_{2}, Q_{5}, Q_{10}, Q_{25}$, or $Q_{50}$ flows, respectively) for reference. 


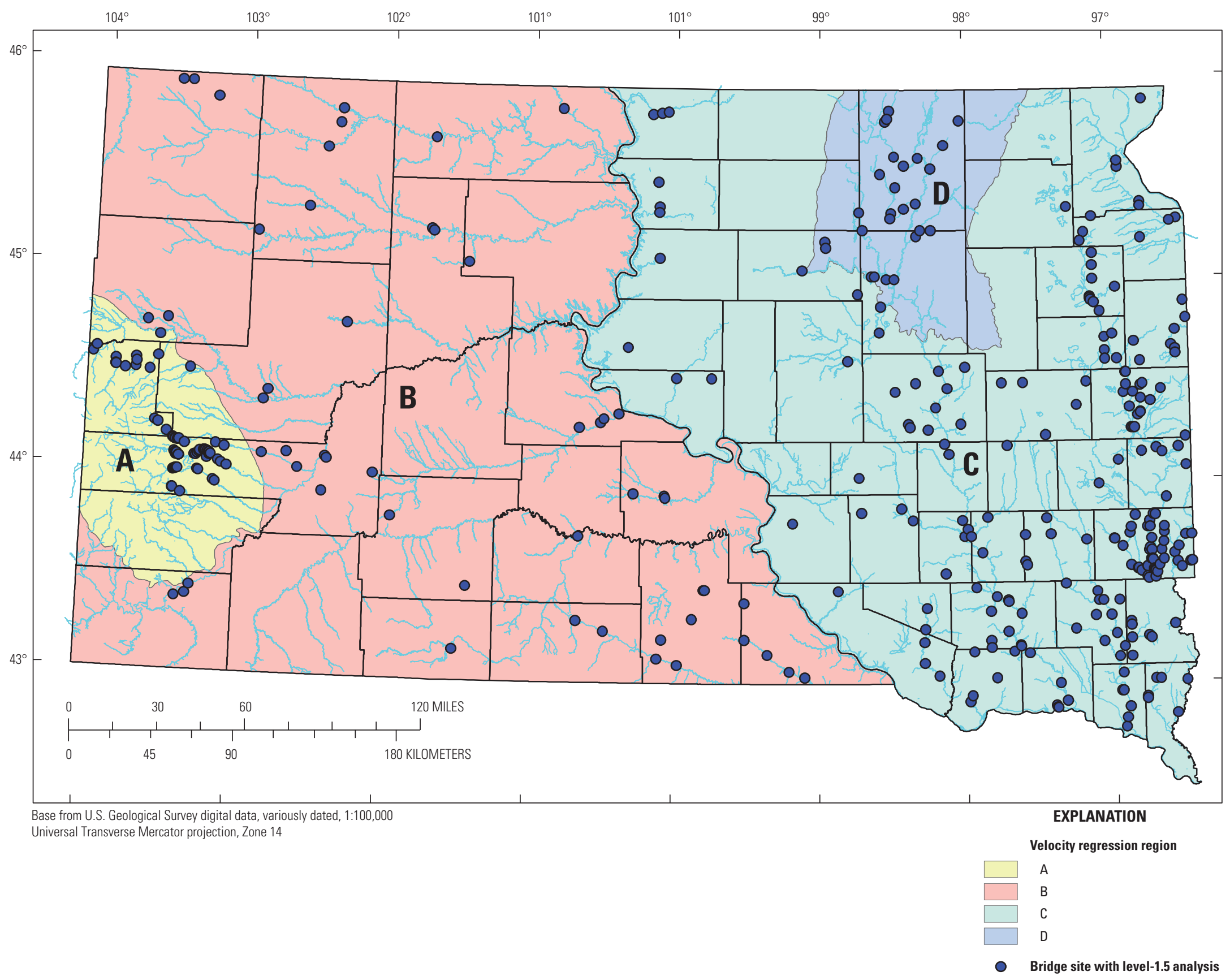

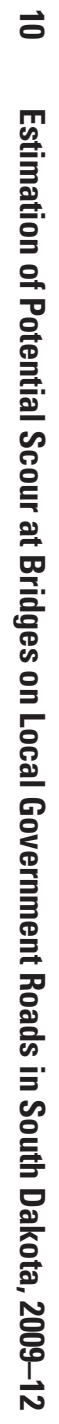

Figure 6. Locations of South Dakota bridges where level-1.5 analyses were completed. 
One of four methods was used to estimate the flows for each bridge before its level-1.5 analyses. For most of the bridges, peak-flow regression equations were used to estimate flows at AEPs of 50, 20, 10, 4, 2, 1, and 0.2 percent (2-, 5-, 10-, 25-, 50-, 100- and 500-year floods). In this way, a flow appropriate to the bridge capacity was available and could be selected on-site. For flows estimated before March 19, 2012, a pre-release version of South Dakota StreamStats (U.S. Geological Survey, 2012) was used to determine basin characteristics for the site, which were then automatically passed to the National Streamflow Statistics Program (U.S. Geological Survey, 2013), and flood estimates were calculated from the Sando (1998) peak-flow magnitude regression equations. Floods estimated after March 19, 2012 , were generated using the final version of South Dakota StreamStats (U.S. Geological Survey, 2013b), which produced the flood estimates using the same equations. A few of the bridges visited for level-1.5 analyses were coincident with streamgages, and peak-flow frequency estimates calculated by Sando and others (2008) were used at these bridges. A few other bridges were on gaged streams and close to the streamgages. If the drainage area at the ungaged site was within 75 to 150 percent of the drainage area of the streamgage, then the drainage area ratio method of Sando (1998) could be used to estimate flows. The method used to estimate the flows at each bridge site is presented in appendix 1 .

\section{Data Presented for Level-1.5 Scour Analyses}

Data presented for level-1.5 scour analyses at the 361 bridges include estimates of contraction, abutment, and pier scour (appendix 1). Field personnel visited the 361 bridges and recorded relevant data for defining variables for input to the separate regression equations described in Holnbeck and Parrett (1997) to estimate contraction scour, abutment scour, and pier scour. Additional details on the level-1.5 methodology were given previously in the section titled "Background for the Rapid Scour-Estimation Technique (Level-1.5 Method)." The level-1.5 field forms contain comments and diagrams that commonly are essential for interpretation of the estimated scour values. For example, the abutment scour equation for the level-1.5 method may yield a scour estimate of 5 feet at the left abutment of a given bridge (left and right are based on the perspective of looking downstream), but comments on the field form may describe existing scour countermeasures, such as riprap or gabion baskets and indicate that the estimated scour may be partially or completely mitigated. Bridges in appendix 1 are sorted alphabetically by county and listed in order of structure number within each county. The original paper level-1.5 field forms, electronic copies of the originals, and digital photographs taken at each bridge will be transmitted to the SDDOT for further use. Electronic copies of the field forms are provided in appendix 2.
Estimates of potential contraction scour at the 361 bridges ranged from 0 to 32.5 feet, with a median of 5.5 feet for the various flows evaluated. Estimates of potential abutment scour ranged from 0 to 40.9 (with a median of 11.9 feet) for left abutments, and from 0 to 37.7 feet (with a median of 11.4 feet) for right abutments. Estimated potential pier scour values ranged from 2.7 to 31.6 feet, with a median of 6.7 feet for the various flows evaluated. Estimated potential scour depths for each bridge are an important risk evaluation tool for SDDOT. The scour depth estimates can be compared to foundation depths at each bridge to determine if abutments or piers are at risk of being undermined by scour at the flows evaluated. Any sites with potentially critical scour conditions can then undergo design of appropriate scour countermeasures.

\section{Quality Assurance/Quality Control of Data}

Replicate analyses were made at 24 of the 361 bridges (approximately 6.6 percent) to provide quality-assurance/ quality-control measures for the level-1.5 scour estimates (fig. 7; appendix 3 as a Microsoft ${ }^{\circledR}$ Excel spreadsheet). The bridges receiving replicate analyses were selected after most of the initial level-1.5 analyses were completed in an attempt to achieve a representative and even spatial distribution of replicate sites. Replicate analyses were completed by having different personnel visit the same bridge at different times and independently complete level-1.5 analyses. Three different individuals, identified in appendix 3 as $\mathrm{A}, \mathrm{B}$, and $\mathrm{C}$, completed these analyses at the selected bridges. For the replicate scour analyses, individual A or B completed the first visit at each of the replicate sites, and individual $\mathrm{C}$ completed the second visit at each replicate site. Because of other work commitments, the three individuals involved each completed differing numbers of level-1.5 analyses. Individual $\mathrm{C}$ was involved in the previous level-1.5 scour study and had previous field experience. Individual $\mathrm{C}$ trained individuals $\mathrm{A}$ and $\mathrm{B}$ on the methodology of the level-1.5 analysis. However, individuals $\mathrm{A}$ and $\mathrm{B}$ completed most of the level-1.5 analyses, and also became experienced in level-1.5 analysis.

As with appendix 1, much additional information valuable to interpreting the results of the replicate scour analyses of appendix 3 is given on the field forms (appendix 2). Many of the differences in replicate results presented in the tables in this report can be traced back to one or more different initial assumptions that are explained in the field forms, but may not be evident in the information included in appendix 3. Contraction, abutment, and pier scour estimates from the level-1.5 method each have multiple variables measured or estimated in the field. Small changes in one variable may not affect the estimated scour depths greatly, whereas small changes in another variable may have a large effect. Many factors affect the reproducibility of scour estimates in replicate visits, including channel geometry at and upstream from the bridge, and the experience level of the individual completing the analysis. Because the replicate 


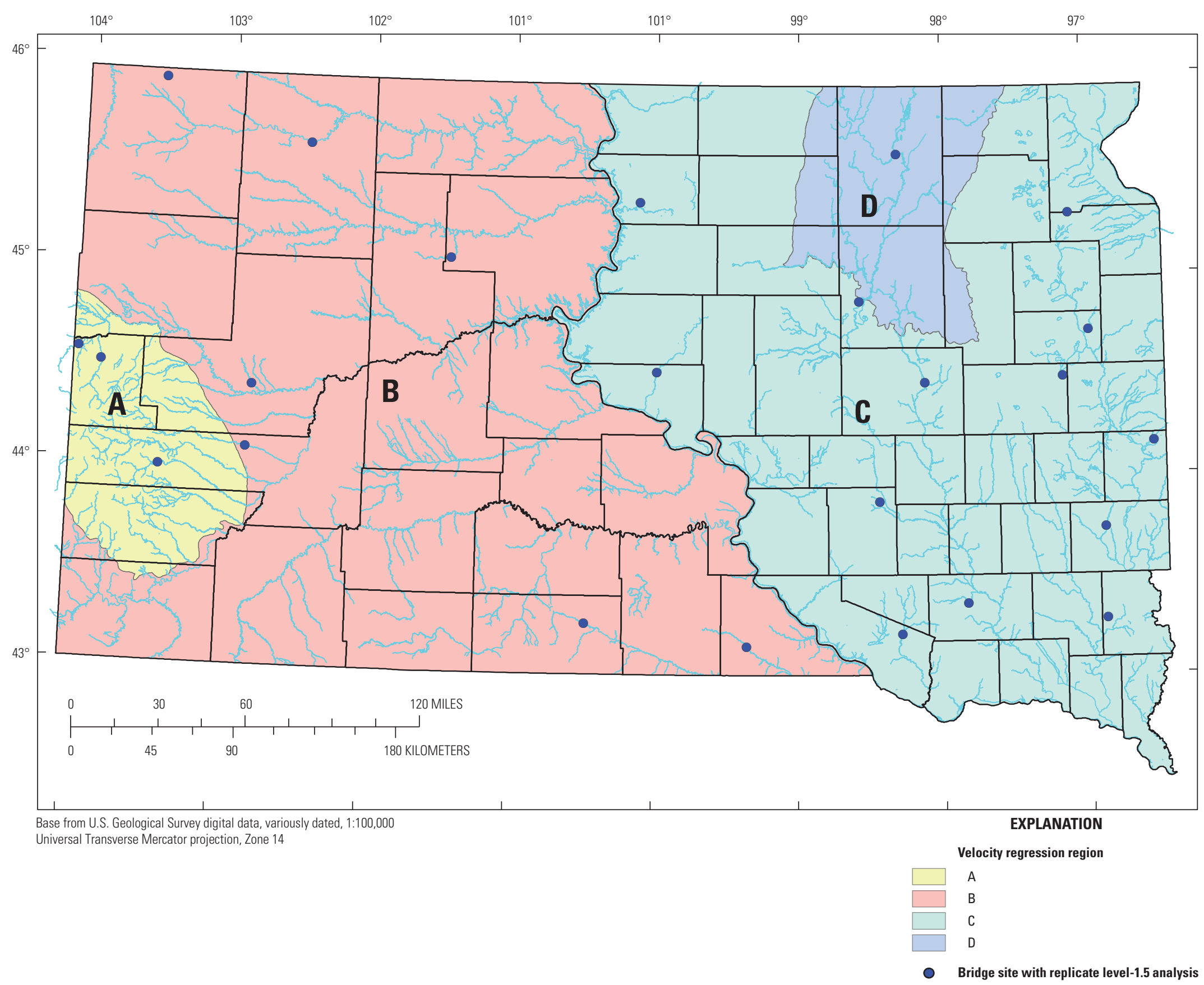

Figure 7. Locations of South Dakota bridges with replicate level-1.5 bridge scour analyses. 
analyses generally were not completed on the same day, it is possible that natural events (such as high flows or debris jam formation) or human activity (such as filling of scour holes or other channel modifications) could have occurred between visits and negatively affected the repeatability of the results. However, this is not expected to have occurred extensively.

An attempt was made to use the same flows among replicate analyses. However, oftentimes one of the flows may result in road overflow. Unless both replicate analyses independently arrived at the same estimated amount of road overflow, the velocity and depth of water through the bridge (and all other parameters affected by these values) can be expected to differ. The mathematics of a scour equation can sometimes interact with certain channel geometries to produce results that are counterintuitive. The fifth site in appendix 3 (structure number 21030282) provides an example of this. Even though there were different interpretations of the width of the main channel at the approach section by individuals A ( $W_{1}$ value of 141 feet) and $\mathrm{C}$ ( $W_{1}$ value of 132 feet), the water surface elevations and the shape of the bridge opening resulted in estimated $Q_{500}$ contraction scour values $\left(y_{\mathrm{cs}}\right)$ that were less than the estimated $Q_{100}$ contraction scour for both analyses. Although the overbank flow depths in the right and left overbanks ( $y_{\text {rob }}$ and $y_{\text {lob }}$, respectively) were greater for $Q_{500}$ than for $Q_{100}$, their contributions to the contraction scour equation are overshadowed by the increase in wetted area. This means that the component of contraction scour resulting from flow constriction in the main channel decreases more than the scour increases because of the overbank depths, resulting in contraction scour being lower at $Q_{500}$ than $Q_{100}$. Appendix 3 would likely show better agreement among replicate analyses if sites with differing initial assumptions were eliminated. However, differing initial assumptions are likely an unavoidable factor if the replicate analyses are completed in a truly independent manner, and thus are included in appendix 3. It is important to note that replicate scour results do not necessarily have to be in numerical agreement to give the same results. For example, if contraction scour replicate estimates are 18.8 feet and 30.8 feet, they both indicate susceptibility to scour for which countermeasures may be needed, even though one number is much greater than the other

Figure 8. Replicate level-1.5 contraction scour estimates at 24 bridge sites in South Dakota. number. These and other factors are described in the following subsections.

\section{Contraction Scour}

Because of the large number of variables that must be estimated (Holnbeck and Parrett, 1997), contraction scour has perhaps the greatest potential for being estimated differently in replicate visits. Two of the early steps in completing a level-1.5 contraction scour analysis are estimating the angle at which the flows analyzed approach the bridge and estimating a point in the bridge opening that represents an average elevation of the channel bottom. In addition to their effect on contraction scour, these two variables also have the potential to affect the estimates for pier and abutment scour. The angle of flow approach sometimes is difficult to estimate because the low-flow channel may intersect the bridge at a substantially different angle than a flood flow if there is a large amount of overbank flow. The angle of flow approach can affect the effective width of the bridge opening and the effective pier width (for webbed piers). The point chosen as the average elevation of the channel bottom is important because it acts as the local datum used to measure overbank flow depths. For bridge sites that have a uniform and flat channel, it is easier to accurately choose an average channel bottom point, relative to bridges with steep or irregular channels or multiple side channels. Figure 8 provides a scatter plot of replicate contraction scour estimates. A 1:1 line indicates

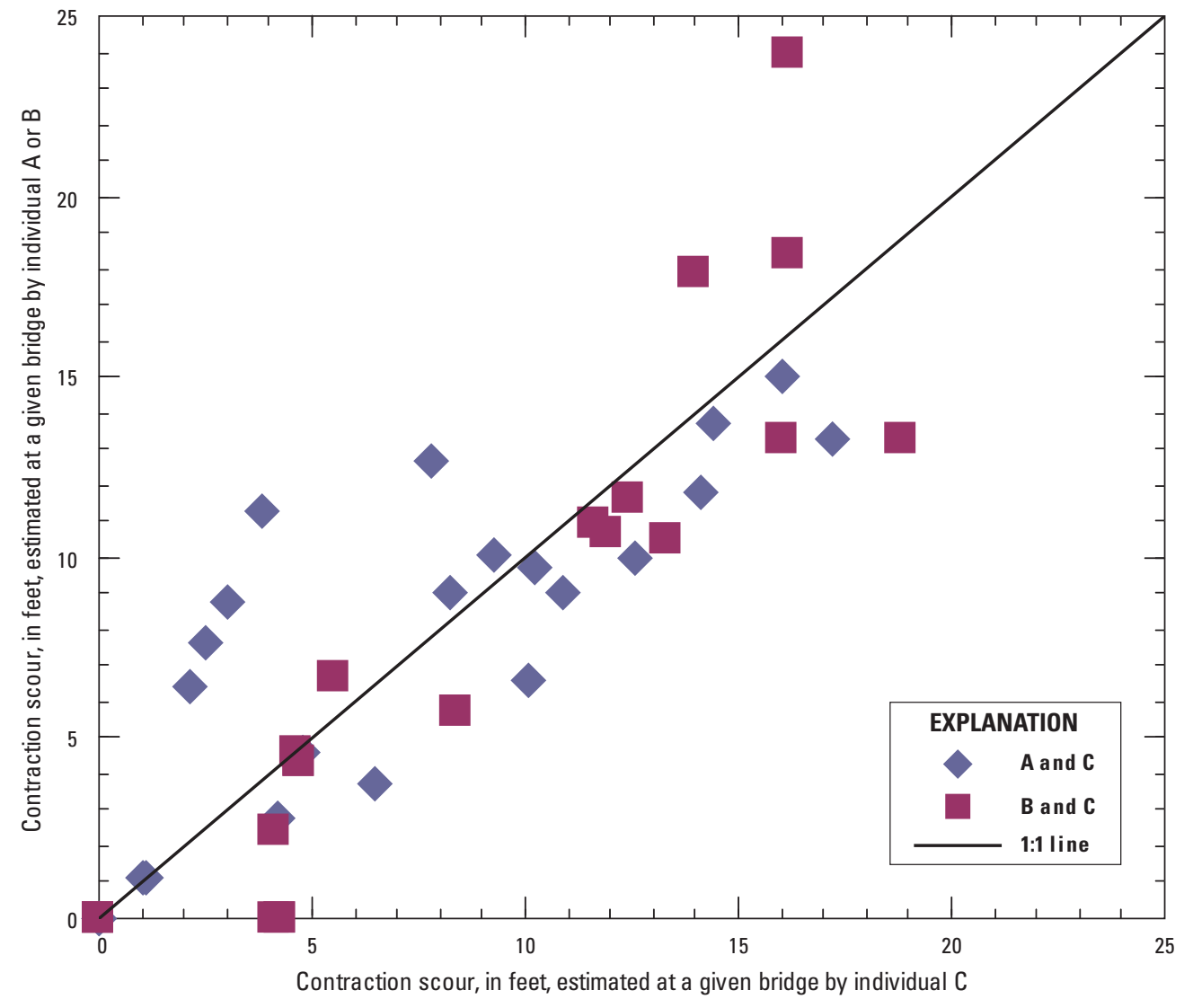


where all points would lie if replicates reproduced results exactly. For contraction scour estimates at the various flows analyzed, differences in results between individual A or B and individual $\mathrm{C}$ ranged from -7.8 to 5.5 feet with a median difference of 0.4 foot and an average difference of 0.2 foot. The two points that plot on the $\mathrm{x}$-axis correspond to bridge 41093081. The bed material at this site was approximately at the size where clear-water contraction may result. Individual $\mathrm{B}$ assumed that clear-water contraction scour would result, whereas individual $\mathrm{C}$ calculated both live-bed and clearwater contraction scour, but reported live-bed in the summary table on the field form. This again stresses the importance of referring to the field forms for additional information.

\section{Abutment Scour}

Abutment scour (fig. 9) appeared to be nearly as reproducible as contraction scour (fig. 8) among replicate analyses. The most likely cause of substantial differences among abutment scour replicates is differing estimates of the overbank width or overbank flow depth in the approach section blocked by the abutment at the bridge section. This, in turn, generally is caused by differing elevations chosen as the average location of the channel bottom, or different locations chosen for the approach section. At a few replicate sites, there were some different interpretations as to which abutment shape coefficient $\left(K_{1}\right.$; Holnbeck and Parrett, 1997, p. 16) was appropriate for the abutment, probably because of varying degrees of erosion and previous scour along the abutments under the bridge. For the abutment scour estimates at the varying flows analyzed, differences in results between individual $\mathrm{A}$ or $\mathrm{B}$ and individual $\mathrm{C}$ ranged from -17.4 to 11 feet, with a median difference of 1.4 feet and an average of 1.7 feet. As with contraction scour, close numeric agreement of abutment scour replicates is not as important as the magnitude of the scour estimates.

\section{Pier Scour}

Estimates of pier scour tended to be the most consistently reproduced scour estimates in replicate visits, with most points clustered near the 1:1 line (fig. 10). Although the values for velocity and depth of flow at the bridge section are the same values required for contraction scour, estimated pier scour is not as sensitive to variations in velocity and flow depth as it is to pier size. Differences in replicate pier scour estimates greater than approximately 1 foot generally are because of differences in assumed flow angle of attack on the pier (at bridges where webbed piers were present), which affects the correction factor for flow angle of attack $\left(K_{2}\right)$ (Holnbeck and Parrett, 1997, p. 10), or differences in estimated pier diameter, such as in cases where the water was too deep to

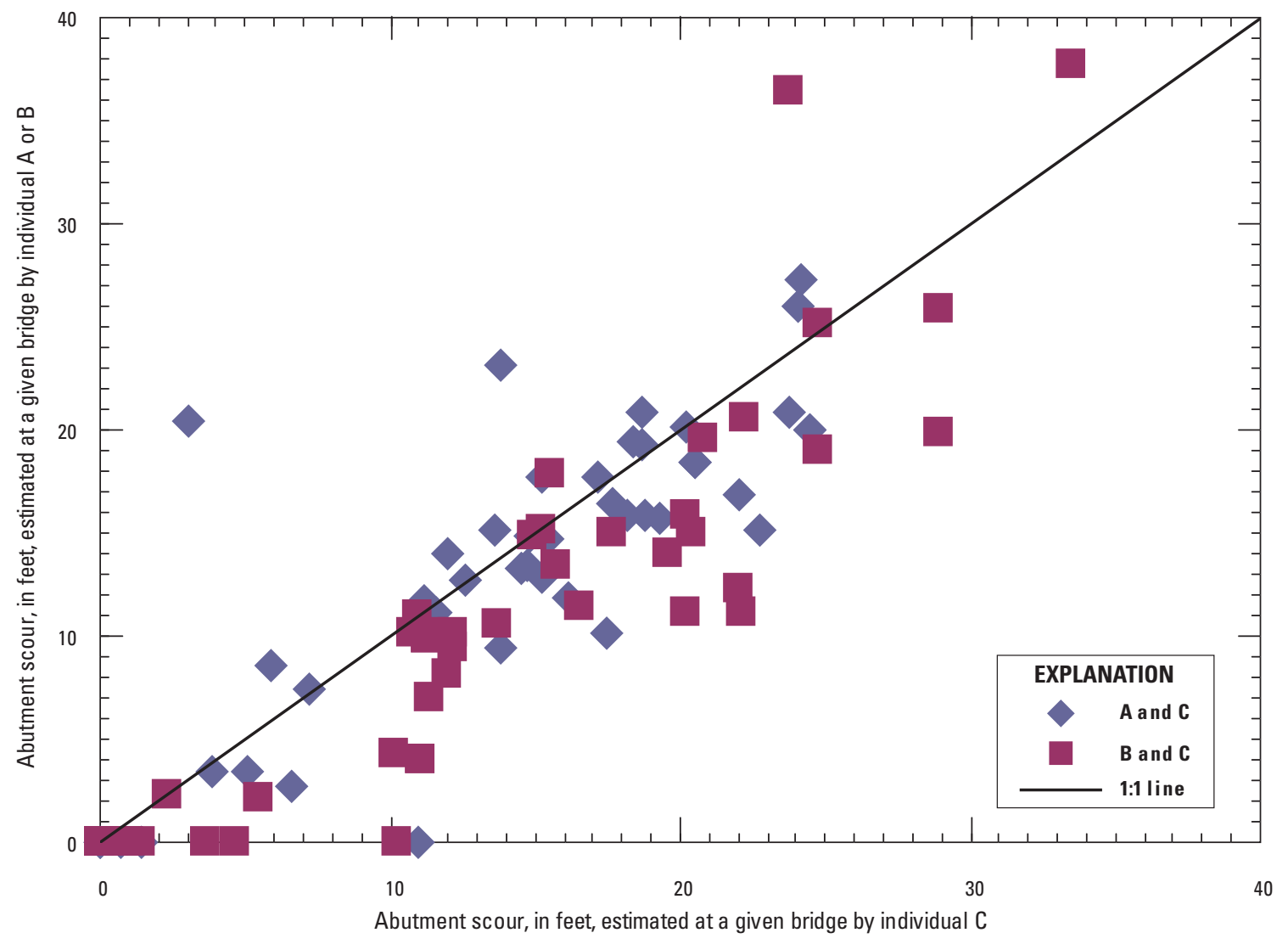

Figure 9. Replicate level-1.5 abutment scour estimates at 24 bridge sites in South Dakota. 


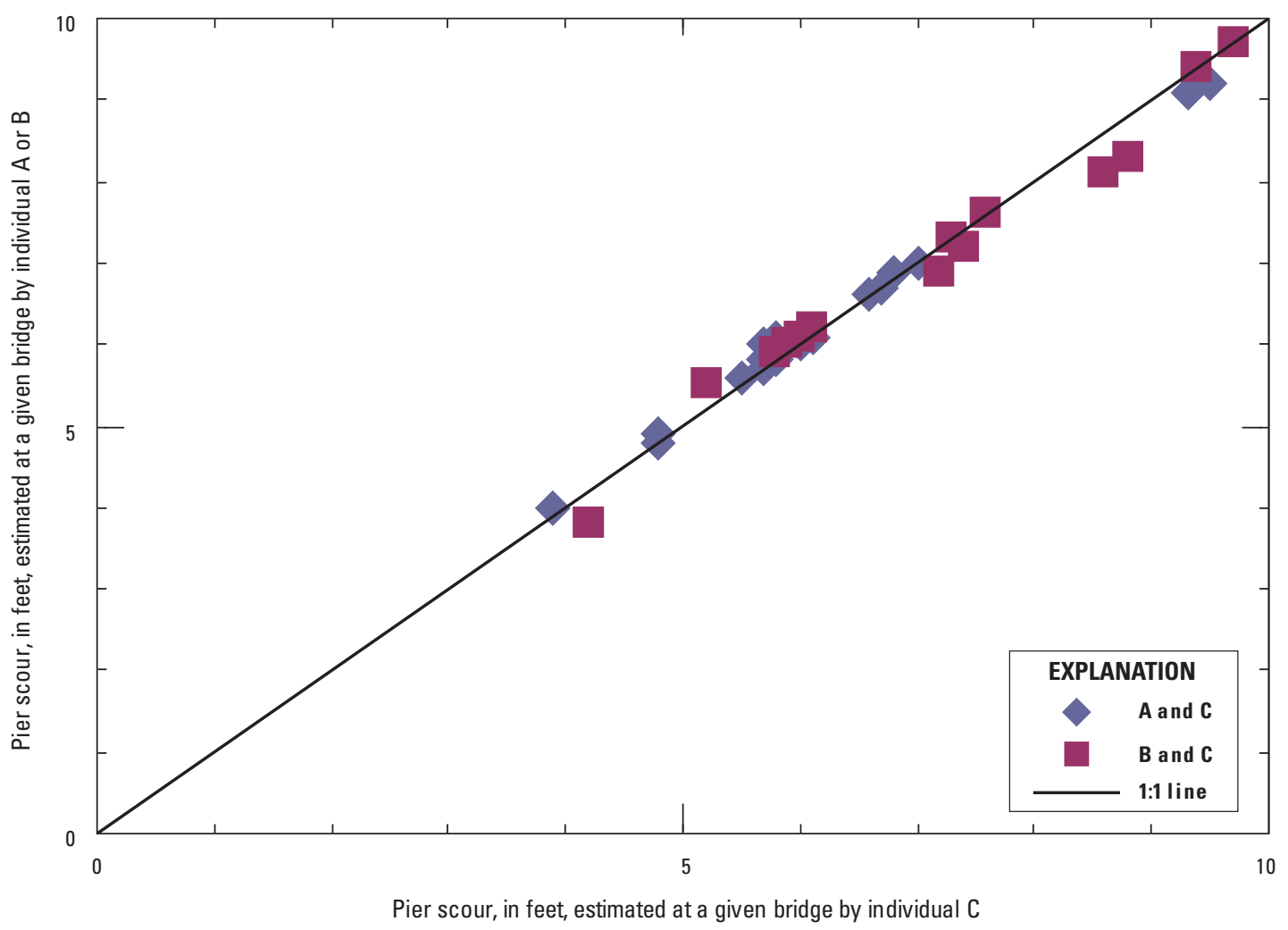

Figure 10. Replicate level-1.5 pier scour estimates at 24 bridge sites in South Dakota.

physically measure the pier by wading. For the pier scour estimates at the varying flows analyzed, differences in results between individual $\mathrm{A}$ or $\mathrm{B}$ and individual $\mathrm{C}$ ranged from 0.5 to -0.3 foot, with a median difference of 0.0 foot and an average of 0.0 foot.

\section{Estimated Potential Bridge Scour- Level-2 Method}

A subset of 41 of the 361 bridges with level-1.5 analyses (about 11 percent) also received a level-2 analysis (fig. 11). Bridges for level-2 analyses were selected to represent the various hydraulic conditions and bridge configurations present across the State. An effort also was made to avoid selecting bridges that were in such a unique setting that it would be difficult to model or represent scour using the standard level1.5 and level-2 methods. Data collection for bridges receiving level-2 analyses was completed in 2009. In 2010, the Federal Highway Administration allowed SDDOT to exempt any bridge with an average daily traffic count of less than 100 from the scour evaluation requirement. Even though some of the level-2 analyses completed in 2009 were on bridges with an average daily traffic count of less than 100, these sites still received a level-1.5 analysis and remained in the study.

Level-2 scour analysis involves hydraulic modeling of a segment of the stream containing the bridge to determine the hydraulic variables that are required to solve equations for the varying scour components. The U.S. Army Corps of Engineers Hydraulics Engineering Center has developed a River Analysis System software package (HEC-RAS; Brunner, 2002a, b) to model stream hydraulics. The HEC-RAS model enables a user to calculate river hydraulic parameters for one-dimensional steady and unsteady flow. The two types of data inputs to the HEC-RAS model are channel geometry and flows. Channel geometry consists of cross sections and their spacing and may include structures, such as bridges, weirs, and culverts. Flow data include discharges and boundary conditions. Channel geometry data for level-2 scour analyses were collected by using a real-time kinematic global navigation satellite system (RTK-GNSS) and a total station set up on temporary control points (or permanent control points, if available) strategically located at each bridge. The RTK-GNSS uses signals from global navigation satellite systems and radio signals between a base, positioned at a known location, and rover to determine accurate horizontal and vertical coordinates of objective points in real-time. The RTK-GNSS surveys conducted meet the requirements for a USGS level-4 survey (Rydlund and Densmore, 2012). A total station is an optical surveying instrument that uses electronic distance measuring techniques and radial orientation to determine the horizontal and vertical locations of objective points in relation to the location of the instrument. Flow data include the estimated $Q_{100}$ and $Q_{500}$ flows, or the flow estimated to produce maximum scour at the bridge $\left(Q_{\text {max scour }}\right)$, as described previously in the "Methods Used for Estimation of Bridge Flows Used in Scour Analyses" section describing level-1.5 analyses. 


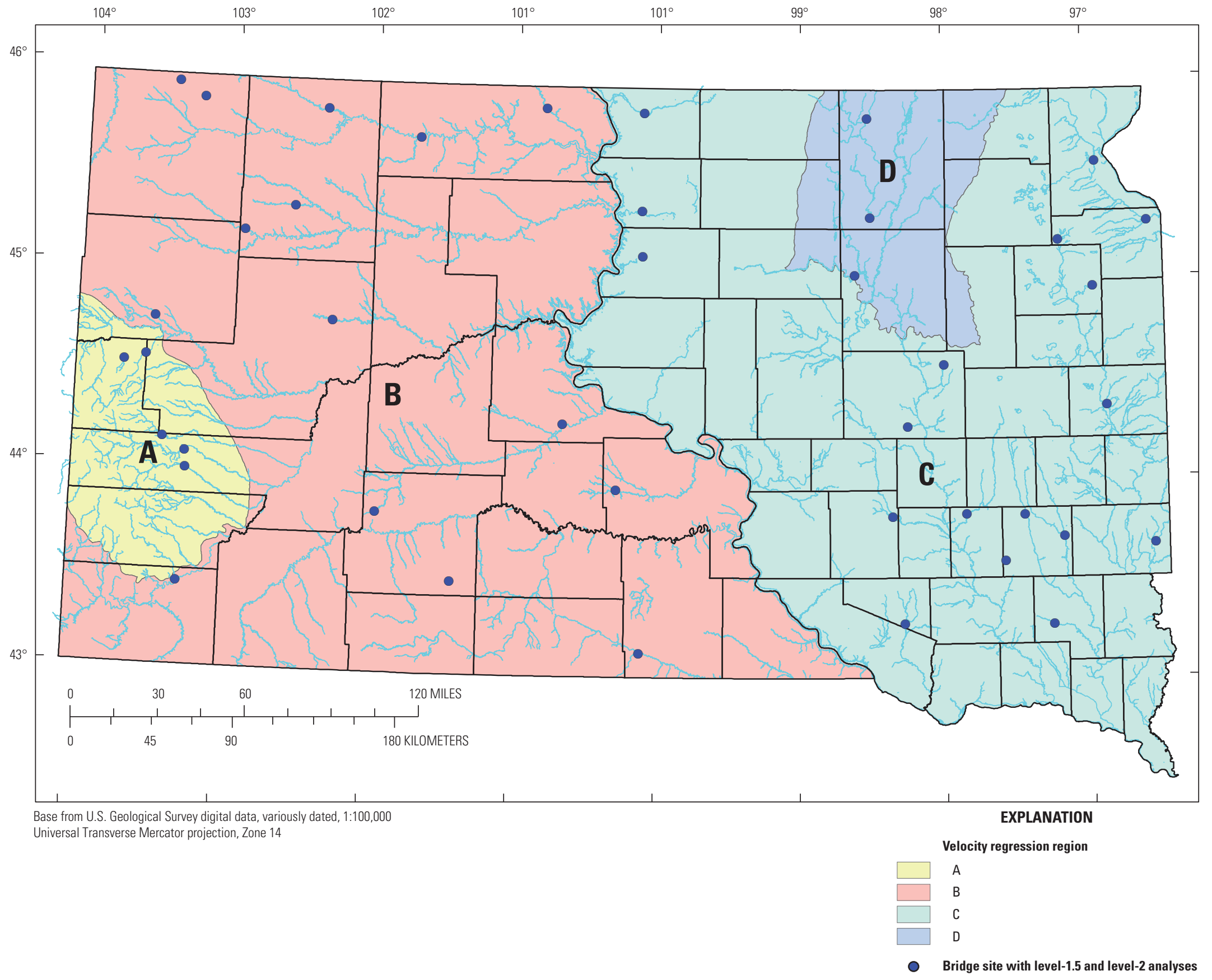

Figure 11. Locations of South Dakota bridges receiving a level-1.5 and level-2 bridge scour analysis, 2009-12. 
The HEC-RAS model also includes a module for estimating scour at modeled bridges. Although HEC-RAS can internally calculate the required inputs for estimating bridge scour from the hydraulic modeling output, the user can change these inputs if desired. The HEC-RAS hydraulic modeling output data were used to populate a series of spreadsheets in which the input parameters were calculated for manual entry into the scour estimation module. This procedure provided greater control of the input parameters. The HEC-RAS model allows the user to select from multiple scour estimation equations in the level-2 scour analyses at bridges. For example, abutment scour can be estimated by using either the Froehlich equation or the Hydraulics in the River Environment (HIRE) equation (Richardson and others, 1991). The user can select one of these equations or allow HEC-RAS to pick which equation is more applicable based on overbank flow depths. Contraction scour can be calculated with different equations for clear-water scour or live-bed scour conditions, depending on model output of water velocity in the channel. Pier scour can be calculated by using the model output of water velocity at each individual pier, or the model output of maximum velocity in the channel can be applied to each pier to allow for a worst-case scenario of channel migration. The pier scour equations available in HEC-RAS are the Froehlich equation or the Colorado State University equation (Richardson and others, 1991).

\section{Comparison of Scour Estimates Between the Level-1.5 and Level-2 Methods}

The performance of the level-1.5 method was assessed by comparing the resulting scour estimates to results from the more rigorous level- 2 method at the 41 sites where both methods were used. The HEC-RAS model was allowed to select the more appropriate contraction scour equation (clearwater or live-bed) and abutment scour equation (Froehlich or HIRE). The maximum channel velocity was applied to all piers, and the Colorado State University equation was used in estimating pier scour for the level-2 method. Scour estimates based on the level-1.5 and level-2 methods are shown in appendix 4 as a Microsoft ${ }^{\circledR}$ Excel spreadsheet.

For each site, the level-1.5 analysis was completed following the construction of the HEC-RAS model used for level-2 analysis. Initially, if the level-1.5 method indicated that the bridge would not pass the estimated $Q_{100}$ flow, analysis was only completed at the flow estimated to cause maximum scour $\left(Q_{\text {max scour }}\right)$. As field work progressed, other flow estimates were noted on field forms, so that some bridges received level-1.5 analyses for AEP flows greater than 1 percent (for example, $Q_{50}$, or other flood frequency intervals less than 100 years). For this reason, some bridges were evaluated for a single flow, whereas others were evaluated at two flows.
The envelope curve approach used in the level-1.5 method is designed to overestimate scour relative to the estimate from the level-2 scour analyses (Holnbeck and Parrett, 1997). As shown in appendix 4, this is generally the case. In cases where the level-1.5 method estimated less scour than the level-2 method, the amount of underestimation generally was less than approximately 3 feet (figs. 12-14). Level-1.5 estimates of contraction scour, abutment scour, and pier scour were plotted in relation to level-2 estimates (figs. 12-14), which are considered more accurate, to enable graphical comparison. Ideally, points should plot near or above the $1: 1$ line.

Special circumstances at some sites affected the agreement between level-2 and level-1.5 scour estimates. At structure number 06131130 (North Deer Creek on 209th Street), the channel was cleaned out some time after the level-2 field visit was completed, but before the level-1.5 analysis. This had a substantial effect on channel geometry and also resulted in smaller contraction and abutment scour estimates being produced by the level-1.5 method relative to the level-2 method. The estimated scour depths associated with this site are highlighted in yellow in figures 12 and 13. Other special circumstances at certain sites are described in the following subsections.

\section{Contraction Scour}

Figure 12 indicates that the level-1.5 method has some difficulty reproducing level- 2 contraction scour estimates. Among the 73 different flows at the 41 sites, the level-1.5 method underestimated contraction scour 38 times, although 14 of these were underestimated by 3 feet or less. Overall, 49 of the 73 contraction scour estimates (about 67 percent) generally reproduced or overestimated contraction scour relative to the level-2 method, as intended. In cases of underestimation by more than 3 feet, differences could be due to difficulty in measuring or estimating level-1.5 variables in the field, or inconsistencies in estimated values of variables (such as approach angles or Manning number) between the methods. If different locations are chosen for the upstream cross section between the level-1.5 and level-2 methods, the potential differences in channel geometry also can affect contraction scour estimates.

Interpretation of bed material also potentially can affect contraction scour estimates. For example, at structure number 32395080 (Coal Bank Creek on county road), the channel was lined with riprap in both ditches and through the bridge opening. During the level-1.5 analysis, the clearwater contraction scour equation was used, with the idea that contraction scour would be zero because of the riprap present. However, the soil sample collected during the level-2 data collection was of soil native to the site, rather than the riprap. Consequently, the HEC-RAS model predicted live-bed contraction scour conditions, resulting in a larger contraction scour estimate than the level-1.5 method. Similar differences 

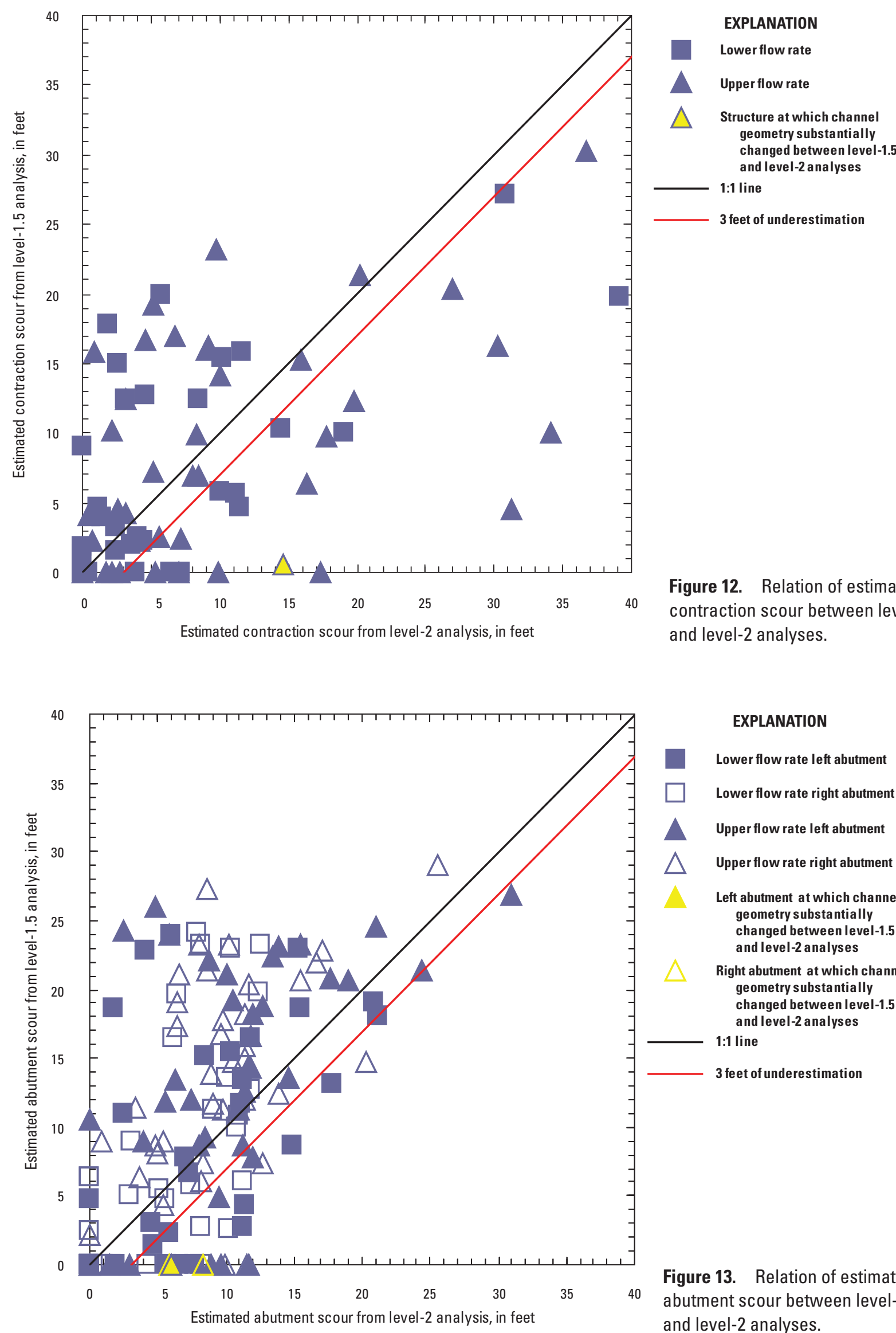

Figure 12. Relation of estimated contraction scour between level-1.5 and level-2 analyses.

\section{EXPLANATION}

Lower flow rate left abutment

Lower flow rate right abutment

Upper flow rate left abutment

Upper flow rate right abutment

Left abutment at which channel

geometry substantially

changed between level-1.5 and level-2 analyses

Right abutment at which channe

geometry substantially changed between level-1.5 and level-2 analyses

1:1 line

3 feet of underestimation

Figure 13. Relation of estimated abutment scour between level-1.5 and level-2 analyses. 
resulted at structure numbers 41165066 (False Bottom Creek on Saint Onge Road), 52399370 (Spring Creek on Spring Creek Road), 52311263 (Boxelder Creek on Nemo Road), and 41238044 (Whitewood Creek on Whitewood Valley Road) where cobble or rock was found in the channel, but the overbanks were covered with soils. These sites account for several of the other points that plot on the $\mathrm{x}$-axis in figure 12 . If contraction scour estimates from these four sites were not included in figure 12, the apparent performance of the level 1.5 method would improve, but several points would still plot below the 3 feet of underestimation line. These points could be associated with sites having a complex channel bottom where, during the level-1.5 analysis, the average bottom of the main channel chosen was too low. Such an occurrence would result in underestimated contraction and abutment scour values.

\section{Abutment Scour}

Figure 13 shows that the level-1.5 method generally overestimated abutment scour relative to the level- 2 method, as intended. As with contraction scour, many of the cases of underestimation were within 3 feet of the $1: 1$ line.

Twenty-eight of the 146 level-1.5 values of abutment scour (approximately 19 percent) were underestimated by more than 3 feet in comparison to level-2 values. As previously described, abutment scour was underestimated by the level1.5 analysis in relation to the level-2 analysis for structure number 06131130 (North Deer Creek on 209th Street) because the channel was modified between field visits; the associated data points are highlighted in yellow on figure 13. Some of the other points that plot below the line indicating 3 feet of underestimation could be associated with sites where a complex channel bottom resulted in the average bottom of the main channel being chosen too low. Some sites with underestimated contraction scour also had underestimated abutment scour values (appendix 4). Although some abutment scour values were underestimated, the level-1.5 method approximates abutment scour better than contraction scour, relative to the level-2 method.

\section{Pier Scour}

Figure 14 shows that the level-1.5 method generally overestimated pier scour relative to the level-2 method, or approximated it within a foot. Although there is still some scatter, pier scour values tend to cluster near or above the 1:1 line. Sixty-five of the 67 points (about 97 percent) are above or within 3 feet of the 1:1 line. The two points where the level-1.5 method underestimated pier scour by more than 3 feet relative to the level-2 method are both flows evaluated at a single site. The larger difference at this site was due to different estimates of the flow angle of attack on a webbed pier. The level-1.5 analysis estimated a smaller angle, which resulted in a lower effective pier width and smaller pier scour estimate.

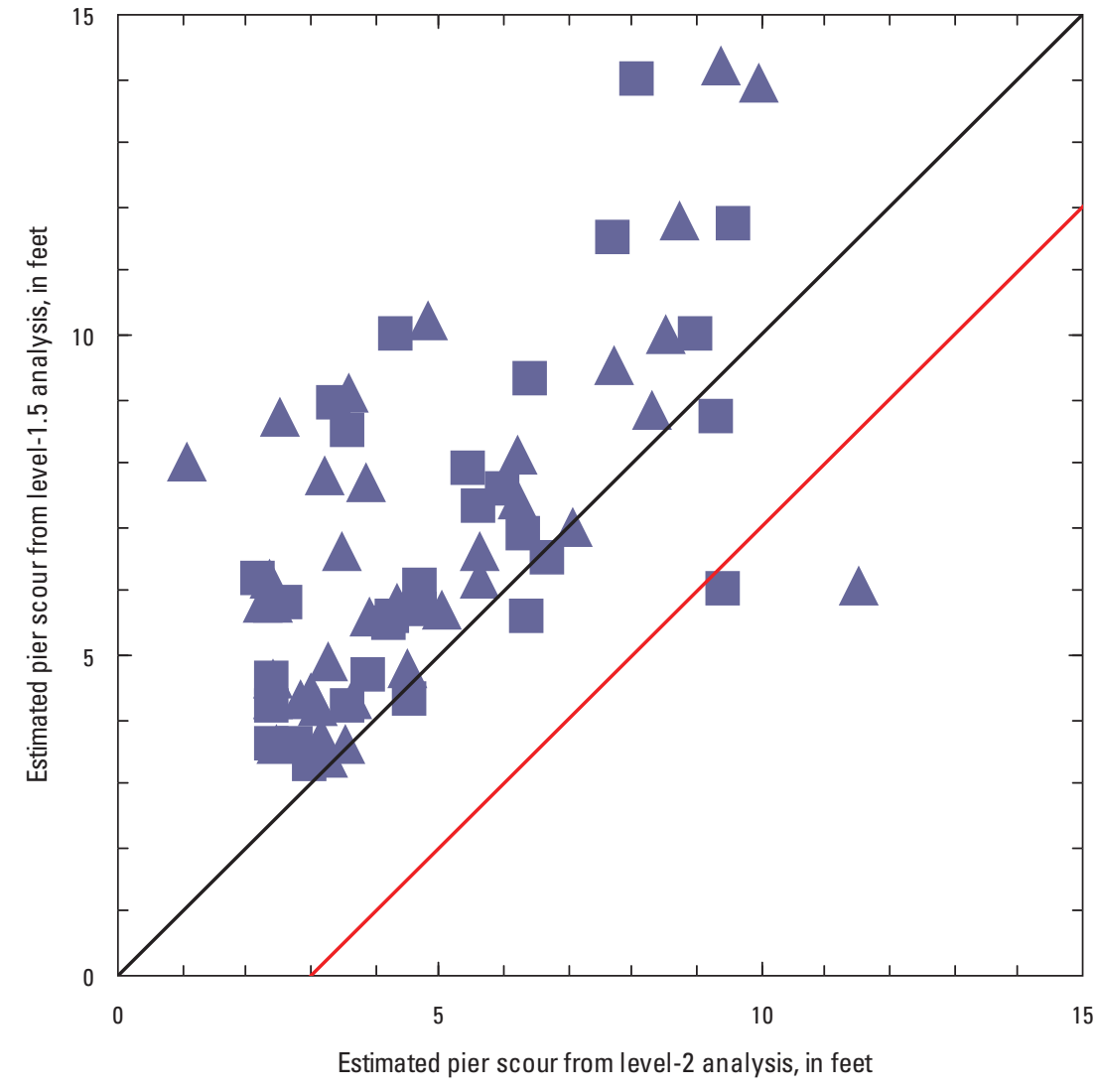

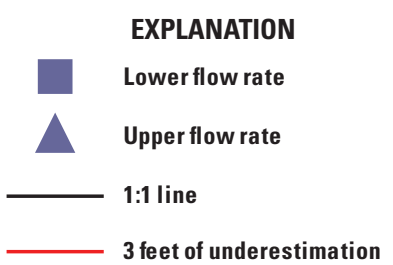

Figure 14. Relation of estimated pier scour between level-1.5 and level-2 analyses. 
Although the level-1.5 method is designed to

overestimate scour relative to more involved analysis methods, many assumptions, uncertainties, and estimations are involved. If the envelope curves are adjusted such that the level-1.5 method never underestimates relative to the level-2 method, an accompanying result may be excessive overestimation.

\section{Summary}

Flowing water can erode (scour) soils and cause structural failure of a bridge by exposing or undermining bridge foundations (abutments and piers), and historically has been a factor in bridge failure. In 2009, the U.S. Geological Survey (USGS) and South Dakota Department of Transportation (SDDOT) began a study to estimate potential scour at selected bridges on local government (county, township, and municipal) roads in South Dakota. Bridge scour analyses typically are classified as level-1, 2, or 3 with the increase in level generally indicating a more complex analysis. Level-1 scour analyses are qualitative, general, and based on a visual inspection of the bridge and stream channel. Level-2 scour analyses are considerably more complex, and data collected at the site are then used in a hydraulics model. Flow parameters from the model, such as velocity and depth, are then used in any of several published scour equations to solve for scour depth. Level-3 scour analyses generally are reserved for complex situations or forensic purposes, and involve extensive mathematical and physical modeling of the selected bridge. A rapid scour-estimation method (level-1.5) developed by the USGS uses limited site data to qualitatively estimate contraction, abutment, and pier scour. Although the level-1.5 method is not intended to replace the more detailed level-2 method, it is useful for completing limited-effort analyses that yield a quantitative result.

For this study, 41 level-2 analyses were completed. Data from these 41 analyses, along with data from level-2 analyses completed in previous studies, were used to develop new South Dakota-specific regression equations. In order to account for the widely varying stream conditions within the State, four equations were developed for main-channel velocity at the bridge contraction based on unit discharge, and a single statewide equation was developed for head change based on average velocity at the bridge constriction. Velocity data from streamgages also were used in the regression for average velocity through the bridge contraction. The velocity regression was completed using 605 data points from hydraulic models at 60 level-2 bridge analysis sites, and 1,323 data points from streamflow measurements made at 176 streamgages. An effort was made to regionalize the velocity regression equations to better reflect the widely varying stream conditions within South Dakota, and four regions were developed. Hydraulic model output for 227 data points from 57 level-2 bridge analysis sites were used to develop the regression equation for head change based on average velocity at the bridge. The head change data were combined to form a single statewide equation.

Using these new regression equations, scour analyses were completed using the level-1.5 method for 361 bridges on local government roads. Typically, level-1.5 analyses are completed at flows estimated to have annual exceedance probabilities of 1 percent (100-year flood) and 0.2 percent (500-year flood). However, at some sites the bridge would not pass these flows. A level-1.5 analysis was then completed at the flow expected to produce the maximum scour. For most of the bridges, peak-flow regression equations were used to estimate the flows for annual exceedance probabilities of 50-, 20-, 10-, 4-, 2-, 1-, and 0.2-percent (2-, 5-, 10-, 25-, 50-, 100-, and 500 -year floods, respectively). In this way, a flow appropriate to the bridge capacity could be selected while at the bridge.

Data presented for level-1.5 scour analyses at the 361 bridges include contraction, abutment, and pier scour. Estimates of potential contraction scour ranged from 0 to 32.5 feet, with a median of 5.5 feet for the various flows evaluated. Estimates of potential abutment scour ranged from 0 to 40.9 feet (with a median of 11.9 feet) for left abutments and 0 to 37.7 feet (with a median of 11.4 feet) for right abutments. Estimated potential pier scour values ranged from 2.7 to 31.6 feet, with a median of 6.7 feet for the various flows evaluated. Estimated potential scour depth data for each bridge are an important risk evaluation tool for SDDOT. The scour depth estimates can be compared to foundation depths at each bridge to determine if abutments or piers are at risk of being undermined by scour at the flows evaluated. Any sites with potentially scour critical conditions can then undergo design of appropriate scour countermeasures.

Replicate analyses were completed at 24 of the 361 bridges to provide quality-assurance/quality-control measures for the level-1.5 scour estimates. Different personnel visited the same bridge at different times and independently completed level-1.5 analyses. An attempt was made to use the same flows among replicate analyses. Scour estimates do not necessarily have to be in numerical agreement to give the same results. For example, if contraction scour replicate analyses are 18.8 and 30.8 feet, both scour depths can indicate susceptibility to scour for which countermeasures may be needed, even though one number is much greater than the other number. Because of the large number of variables that must be estimated, contraction scour has perhaps the greatest potential for being estimated differently in replicate visits. For contraction scour estimates at the various flows analyzed, differences between results ranged from -7.8 to 5.5 feet, with a median difference of 0.4 foot and an average difference of 0.2 foot. Abutment scour appeared to be nearly as reproducible as contraction scour. For abutment scour estimates at the varying flows analyzed, differences between results ranged from -17.4 to 11.0 feet with a median difference of 1.4 feet and an average difference of 1.7 feet. Estimates of pier scour tended to be the most consistently reproduced in replicate visits, with differences between results ranging from -0.3 to 0.5 foot, with a median difference of 0.0 foot and an average difference of 0.0 foot. 
The 41 sites with level-2 analyses also received a level1.5 analysis. The U.S. Army Corps of Engineers Hydraulics Engineering Center River Analysis System (HEC-RAS) software package was used to model stream hydraulics at the level-2 sites. The performance of the level-1.5 method was assessed by comparing results to those from the more rigorous level-2 method. For each site, the level-1.5 analysis was completed following the construction of the HEC-RAS model. The envelope curve approach used in the level-1.5 method is designed to overestimate scour relative to the estimate from the level-2 scour analysis. In cases where the level-1.5 method estimated less scour than the level-2 method, the amount of underestimation generally was less than approximately 3 feet. Overall, 49 of the 73 contraction scour estimates (about 67 percent) generally reproduced or overestimated contraction scour relative to the level-2 method, as intended. The level-1.5 method also generally overestimated abutment scour relative to the level-2 method, as intended. Although some abutment scour values were still underestimated, the level-1.5 method approximates abutment scour better than contraction scour, relative to the level-2 method. The level-1.5 method generally overestimated pier scour relative to the level-2 method, or approximated it within a foot. About 97 percent of estimates for the level-1.5 method were greater than or within 3 feet of the estimates for the level-2 method. Although the level-1.5 method is designed to overestimate scour relative to more involved analysis methods, many assumptions, uncertainties, and estimations are involved. If the envelope curves are adjusted such that the level-1.5 method never underestimates scour relative to the level-2 method, an accompanying result may be excessive overestimation.

\section{References Cited}

Brunner, G.W., 2002a, HEC-RAS, River Analysis System Hydraulic Reference Manual: U.S. Army Corps of Engineers Hydrologic Engineering Center CPD-69, 350 p.

Brunner, G.W., 2002b, HEC-RAS, River Analysis System User's Manual: U.S. Army Corps of Engineers Hydrologic Engineering Center CPD-68, $420 \mathrm{p}$.

Bryce, Sandra, Omernik, J.M., Pater, D.E., Ulmer, Michael, Scharr, Jerome, Freeouf, Jerry, Johnson, Rex, Kuck, Pat, and Azvedo, S.H., 1998, Ecoregions of North Dakota and South Dakota: Jamestown, N. Dak, Northern Prairie Wildlife Research Center, accessed March 1, 2010, at http:// www.npwrc.usgs.gov/resource/habitat/ndsdeco/index.htm.

Butch, G.K., 1991, Measurement of bridge scour at selected sites in New York, excluding Long Island: U.S. Geological Survey Water-Resources Investigations Report 91-4083, 17 p., accessed September 9, 2013, at http://pubs.usgs.gov/ wri/1991/4083/report.pdf.
Holmes, R.R., Jr., and Dinicola, Karen, 2010, 100-Year flood-it's all about chance: U.S. Geological Survey General Information Product 106, 1 p., accessed September 5, 2013, at http://pubs.usgs.gov/gip/106/.

Holnbeck, S.R., and Parrett, Charles, 1997, Method for rapid estimation of scour at highway bridges based on limited site data: U.S. Geological Survey WaterResources Investigations Report 96-4310, 79 p., accessed September 5, 2013, at http://pubs.usgs.gov/wri/1996/4310/ report.pdf.

Huizinga, R.J., and Rydlund, P.H., Jr., 2004, Potentialscour assessments and estimates of scour depth using different techniques at selected bridge sites in Missouri: U.S. Geological Survey Scientific Investigations Report 2004-5213, 42 p. (Also available at $h t t p: / / p u b s . u s g s . g o v /$ $\operatorname{sir} / 2004 / 5213 /$.

Lagasse, P.F., Schall, J.D., Johnson, F., Richardson, E.V., and Chang, F., 1991, Stream stability at highway structures: U.S. Department of Transportation Publiction No. FHWA-IP-90-014, Hydraulic Engineering Circular No. 20 (HEC 20), 195 p.

Niehus, C.A., 1996, Scour assessments and sediment-transport simulation for selected bridge sites in South Dakota: U.S. Geological Survey Water-Resources Investigations Report 96-4075, 80 p., accessed September 9, 2013, at http://pubs. usgs.gov/wri/1996/4075/report.pdf.

Richardson, E.V., Harrison, L.J., and Davis, S.R., 1991, Evaluating scour at bridges: U.S. Department of Transportation Publication No. FHWA-IP-90-017, Hydraulic Engineering Circular No. 18 (HEC 18), 105 p.

Rydlund, P.H., Jr., and Densmore, B.K., 2012, Methods of practice and guidelines for using survey-grade global navigation satellite systems (GNSS) to establish vertical datum in the United States Geological Survey: U.S. Geological Survey Techniques and Methods, book 11, chap. D1, $102 \mathrm{p}$. with appendixes. (Also available at $h t t p: / / p u b s$. usgs.gov/tm/11d1/.)

Sando, S.K., 1998, Techniques for estimating peak-flow magnitude and frequency relations for South Dakota Streams: U.S. Geological Survey Water-Resources Investigations Report 98-4055, 48 p. (Also available at http://pubs.usgs.gov/wri/wri98-4055/.)

Sando, S.K., Driscoll, D.G., and Parrett, Charles, 2008, Peakflow frequency estimates based on data through water year 2001 for selected streamflow-gaging stations in South Dakota: U.S. Geological Survey Scientific Investigations Report 2008-5104, 367 p., accessed September 9, 2013, at http://pubs.usgs.gov/sir/2008/5104/.) 
South Dakota State Historical Society, Historic bridges in South Dakota, 1893-1942: accessed December 4, 2013, at http://history.sd.gov/preservation/OtherServices/ StoneArchCulvertsTurnerCo.pdf.

Thompson, R.F., and Fosness, R.L., 2008, Estimation of potential bridge scour at bridges on State routes in South Dakota, 2003-07: U.S. Geological Survey Scientific Investigations Report 2008-5161, 18 p., accessed September 9, 2013, at http://pubs.usgs.gov/sir/2008/5161/.)

U.S. Department of Transportation, 1988, Scour at bridges: Washington, D.C., Federal Highway Administration Technical Advisory T 5140-20, 6 p.

U.S. Department of Transportation, 2013, National Bridge Inventory (NBI) database, accessed September 9, 2013, at http://www.fhwa.dot.gov/bridge/nbi/no10/county.cfm.
U.S. Geological Survey, 2012, National Streamflow Statistics Program: accessed July 1, 2013, at http://water.usgs.gov/ osw/programs/nss/.

U.S. Geological Survey, 2013a, National Water Information System (NWISWeb) - USGS surface-water data for South Dakota: U.S. Geological Survey database, accessed June 26, 2009, at http://waterdata.usgs.gov/sd/nwis/sw/.)

U.S. Geological Survey, 2013b, StreamStats-South Dakota: accessed October 18, 2011, at http://water.usgs.gov/osw/ streamstats/south_dakota.html.)

Williams-Sether, Tara, 1999, Estimated and measured bridge scour at selected sites in North Dakota, 1990-97: U.S. Geological Survey Water-Resources Investigations Report 99-4124, 54 p. (Also available at http://pubs.usgs. gov/wri/1999/4124/report.pdf.) 
Appendixes 1-4 


\section{Appendix 1. Selected Information from the Level-1.5 Analyses of Scour at 361 Bridges on Local Government Roads in South Dakota}

Selected information from the level-1.5 analyses of scour at 361 bridges on local government roads in South Dakota was compiled for appendix 1 and organized into a Microsoft ${ }^{\circledR}$ Excel spreadsheet (file Appendix_1.xls) that contains two worksheets. In the spreadsheet, the worksheet named "Readme" contains descriptions of the headings used in the table of its corresponding worksheet.

\section{Appendix 2. The Level-1.5 Field Forms for the 361 Bridge Sites on Local Government Roads in South Dakota}

The scanned level-1.5 field forms for the 361 bridge sites and associated duplicate field forms for the 24 bridges with replicate analyses are provided as pdf files in a downloads directory for appendix 2 . The pdf files for appendix 2 are named by using the structure number (appendix 1); for the pdf files for the 24 bridges with replicate analyses, the word "duplicate" appears after the structure number in the pdf name.

\section{Appendix 3. Selected Information from the Level-1.5 Replicate Analyses of Scour at 24 Bridges on Local Government Roads in South Dakota}

Selected information from the level-1.5 replicate analyses of scour at 24 bridges on local government roads in South Dakota was compiled for appendix 3 and organized into a Microsoft ${ }^{\circledR}$ Excel spreadsheet (file Appendix_3.xls) that contains two worksheets. In the spreadsheet, the worksheet named "Readme" contains descriptions of the headings used in the table of its corresponding worksheet.

\section{Appendix 4. Selected Information from the Level-1.5 and Level-2 Analyses at 41 Bridges on Local Government Roads in South Dakota}

Selected information from the 41 bridges on local government roads in South Dakota with both level-1.5 and level-2 analysis was compiled for appendix 4 and organized into a Microsoft ${ }^{\circledR}$ Excel spreadsheet (file Appendix_4.xls) that contains two worksheets. In the spreadsheet, the worksheet named "Readme" contains descriptions of the headings used in the table of its corresponding worksheet.

\footnotetext{
Publishing support provided by:
}

Rolla Publishing Service Center

For more information concerning this publication, contact:

Director, USGS South Dakota Water Science Center

1608 Mountain View Road

Rapid City, South Dakota 57702

(605) 394-3200

Or visit the South Dakota Water Science Center Web site at: 
Back cover. Top to bottom: Woody debris from a previous high flow event at bridge 10262330 over Indian Creek in Butte County, South Dakota, October 28, 2011. Photograph by Chelsea Wattier, U.S. Geological Survey. Armoured abutment at bridge 16149190 over the Grand River in Corson County, South Dakota, October 29, 2011. Photograph by Chelsea Wattier, U.S. Geological Survey. Orange markers denoting the estimated stage at the two flows analyzed for bridge 14120183 over the Vermillion River in Clay County, South Dakota, May 27, 2012. Photograph by Ryan Truax, U.S. Geological Survey. 


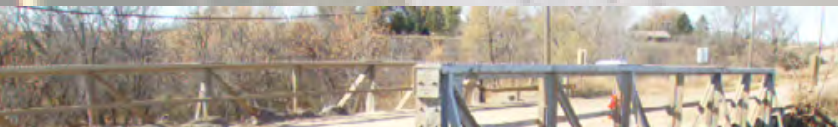

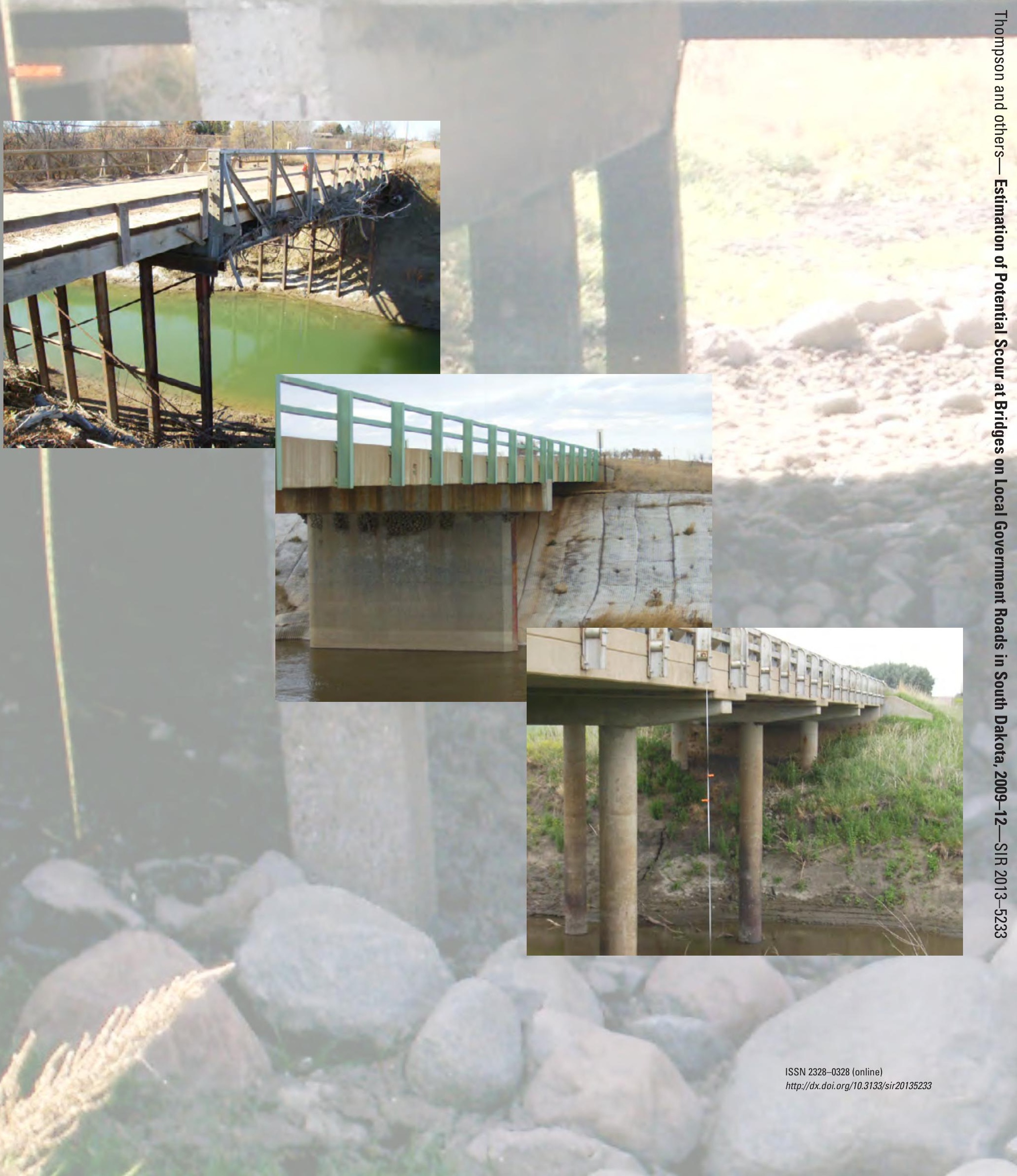

